\title{
ABD’nin 1974 Kıbrıs Askeri Darbesindeki Rolü
}

\author{
DOI: $10.26466 /$ opus.521229 \\ *
}

\section{$\underline{\text { Altuğ Günal }}^{*}$}

* Doç. Dr, Ege Üniversitesi, İ̈BF, Bornova/İzmir/Türkiye

E-Posta: altuggunal@gmail.com

ORCID:0000-0003-3227-8691

\section{Öz}

1960 Kıbrıs Cumhuriyeti'nin Cumhurbaşkanı Makarios, ülkesini Bağlantısızlar Hareketine dahil etmiş ve SSCB başta olmak üzere Doğu Kampıyla iyi ilişkiler geliştirmiştir. Buna, NATO üyesi Yunanistan ve Türkiye ile sorunlar yaşaması ve içeride komünist partinin desteğini alması da eklenince, ABD yönetimleri durumdan rahatsız olmuștur. 1974 Temmuz'unda, cunta yönetimindeki Yunanistan, Kıbrıs'ta bir darbe organize etmiş ve Makarios'u devirmiş̧ir. Bir çok Avrupa ülkesi darbeyi kınarken ABD; yumuşak bir açıklama yapmış, Yunanistan'a askeri yardımını kesmemiş, Makarios'u göreve döndürmek konusunda isteksiz davranmış ve darbeyi ya da ardından gelen Türk müdahalesini durdurmak için güç kullanmayı reddetmiştir. Bu gelişmeler, ABD'nin adayı NATO etki alanına sokmak için darbeye ve devamında Türkiye'nin adanın \%37'sini ele geçirmesine destek vermiş olduğuna dair argümanların ortaya atılmasına neden olmuştur. Bu çalışma ise söz konusu argümanları destekleyecek yeterli kanıtın mevcut olmadığını savunmaktadır. ABD'nin 1960-1974 arası Kıbrıs ile ilgili öncelikleri, adanın; Türkiye ve Yunanistan arasında çatışma yaratmayacak ve Doğu Akdeniz'deki NATO işbirliğine zarar vermeyecek kadar istikrarlı kalması, Doğu Bloğu ile fazla yakınlaşmaması ve SSCB'yi soruna müdahil edecek bir firsat yaratmaması olmuştur. ABD açısından Makarios, bu önceliklere yönelik, ortadan kaldırılmasını gerektirecek kadar büyük bir tehdit oluşturmamıştır.

Anahtar Kelimeler: Kıbris Cumhuriyeti, ABD, Makarios, Kissinger, Darbe 


\title{
USA's Role in 1974 Cyprus Military Coup
}

\begin{abstract}
Makarios, the president of the 1960 Republic of Cyprus, had incorporated his country into the NonAligned Movement and developed good relations with the East Camp, and particularly the USSR. In addition to these, he had problems with NATO Allies Greece and Turkey and took support from the communist party of Cyprus. Naturally, the US administrations had been discontent with these developments. In July 1974, Greece under junta rule, organized a coup in Cyprus and overthrew Makarios. While many European countries condemned the coup; USA gave a soft response, refrained from cutting its military aid to Greece, was reluctant to reinstate Makarios and refused to use force to stop the coup or subsequent Turkish intervention. These developments created arguments, which defended that the United States supported the coup and Turkey's military intervention, in order to put Cyprus under NATO influence. However, this study defends that there is not enough evidence to support these arguments. The priorities of the USA on Cyprus between 1960-1974 were, ensuring the island's stability so that it won't; cause a clash between Turkey and Greece, weaken the NATO cooperation in the Eastern Mediterranean, seek alliance with Soviets and create an opportunity for USSR to be involved in the problem. Within the framework of these priorities, Makarios did not pose a serious threat to the US.
\end{abstract}

Keywords: Republic of Cyprus, USA, Makarios, Kissinger, Military Coup 


\section{Giriş}

Uzun süreçli çatışmaların ve siyasi krizlerin ardından 16 Ağustos 1960'da Kıbrıs Cumhuriyeti (KC) bağımsız bir devlet olarak ortaya çıkmıştır. Aynı gün $\mathrm{ABD}$ bu yeni devleti tanımış ve Lefkoşa' daki başkonsolosluğunu büyükelçiliğe yükselterek diplomatik ilişkilerini başlatmıştır (Office of the Historian [OOTH]). ABD'nin, bu tarihten Türkiye'nin Kıbrıs'a askeri müdahalede bulunduğu 1974 yılının sonuna kadarki öncelikli Kıbrıs siyaseti ise dört başlıkta toplanabilir: Birincisi, adanın Türkiye ve Yunanistan arasında çatışma yaratmayacak ve Doğu Akdeniz'deki NATO işbirliğine zarar vermeyecek kadar ${ }^{1}$ istikrarlı kalmasıdır. İkincisi, Kıbrıs yönetiminin adadaki üsler ve tesisler konusunda sorun yaşatmamasıdır. Üçüncüsü, yönetimin Komünist eğilim içerisine girip Doğu Bloğu ile fazla yakınlaşmaması, dördüncüsü ise Sovyet Sosyalist Cumhuriyetler Birliği'ni (SSCB) soruna müdahil edecek bir fırsat yaratmamasıdır (OOTH, 2018, ss.2848-2878).

Cumhurbaşkanı Başpiskopos Makarios, bağımsızlıktan bir yıl sonra ülkesini Bağlantısızlar Hareketine dahil etmiş (MFA) ve SSCB başta olmak üzere Doğu Kampıyla iyi ilişkiler geliştirmiştir. Buna, Yunanistan ve Türkiye ile sorunlar yaşaması ve içeride komünist partilerin desteğini alması eklenince, Makarios Akdeniz'in Castro'su (Lindsay, 2011, s. 18) olarak anılmaya başlamıştır. Soğuk Savaş koşulları içerisinde, jeostratejik açıdan oldukça önemli bulunan Kıbrıs'taki söz konusu gelişmeler doğal olarak ABD yönetimlerini rahatsız etmiştir.

1974 Temmuz'unda, cunta yönetimindeki NATO müttefiği Yunanistan, Kıbrıs'ta bir darbe organize etmiş ve sorunlar yaşadığı Makarios'u devirmiştir. Bir çok Avrupa ülkesi bu darbeyi kınarken ABD; yumuşak bir açıklama yapmış, darbenin sorumlusu Yunanistan'a askeri yardımını kesmemiş, cuntaya sert eleştirilerde bulunmamış, Makarios'u göreve döndürmek konusunda isteksiz davranmış, ardından gelen Türk müdahalesine sert tepki göstermemiş ve darbe ya da müdahaleyi durdurmak için güç kullanmayı reddetmiştir. Bu gelişmeler $\mathrm{ABD}^{\prime}$ nin, darbeye ve devamında NATO üyesi Türkiye'nin adanın \%37'sini ele geçirmesine onay ya

\footnotetext{
${ }^{1}$ Örneğin Yunanistan ve Türkiye 1964 Ağustos'unda NATO'ya tahsis ettiği bazı kuvvetlerini, Kıbrıs'ı diğerinin saldırısına karşı koruma ihtiyacı nedeniyle çekmiştir (New York Times 1964a).
} 
da destek vermiş olduğuna dair argümanların ortaya atılmasına neden olmuştur.

1974'te Kıbrıs'ta yaşananların ABD'nin onayı ile gerçekleştiğini ve hatta Türk ve Yunan hükümetlerinin bu konuda iş birliği yapmış olabileceğini tamamen ya da kısmen savunan çalışmalar arasında önde gelenler; Andreas Constandinos (2009), Brendan O'Malley ve Ian Craig (1999), Laurence Stern (1975), Prokopis Vanezis (1979), Christopher Hitchens (2002), Christalla Yakinthou (2009) ve William Mallinson'un (2011) eserleridir. Wenzke ve Lindley (2011) ise kapsamlı çalışmalarında yukarıda anılan argümanları "komplo teorisi" olarak değerlendirmişlerdir.

Bu çalışma, modern Kıbrıs tarihinin en kritik dönemi olarak kabul edilen 1974 yılında yaşananlarda ABD'nin ne kadar payı olduğu sorusuna, bir makalenin hacim sınırları içerisinde, kesin bir tarafsızlıkla cevap vermeye çalışmaktadır. Bu çerçevede yazar, esasen ABD'nin basılı ve dijital olarak kullanıma açtı̆̆ 1 arşivlerin (Office of the Historian-Foreign Relations of the United States-FRUS) yanı sıra, yukarı bahsi geçen eserler ve diğer ikincil kaynakları incelemektedir. Bununla birlikte, çok sayıda dayanaksız bilginin ve dezenformasyonun olduğu 1974 Kıbrıs' ına dair çalışma yapmanın, arşivlerin açılması için gerekli olan 30 yıl dolmuş olmasına rağmen oldukça zor olduğunu belirtmek gerekir. Nitekim Yunanistan ve Türkiye, Kıbrıs konusundaki kritik dönemlere ait arşiv belgelerine ulaşım izni vermemektedir. ABD ve İngiltere, bu dönem için arşivlerini açmışsa da, asıl kritik bölümleri halen sansürlü tutmaktadır. Yine de erişime açık belgeler, hatıratlar ve mülakatların, tüm kısıtlarına rağmen dönem hakkında makul derecede fikir verdiği söylenebilir.

İncelediği kaynaklar çerçevesinde bu çalışma, 1974'te Kıbrıs'ta yaşananların; ABD'nin onayı ya da desteğiyle gerçekleştiğini iddia edebilmek için yeteri kadar veri olmadığını savunmaktadır. Dönem boyunca, Kıbrıs bir yandan kendi iç sorunları ile mücadele ederken diğer yandan kutuplardan bağımsız kalmaya çalışmıştır. Türkiye ve Yunanistan, kendi geleneksel tezlerini gerçekleştirmeye çalışırken ABD de, yukarıda anılan dört öncelikli siyasetini istikrarlı bir şekilde uygulamaya devam etmiştir. ABD, Makarios'un bazı politikalardan rahatsız olsa da, onu ortadan kaldırmak isteyecek kadar Batı karşıtı veya tehlikeli görmemiştir. Nitekim Rumların büyük çoğunluğunun desteklediği ve meşru gördüğü bir liderin ortadan 
kaldırılması için cebir kullanılması, bölgenin istikrarı ve sonuçlarının belirsizliği açısından da mantıklı değildir. Ayrıca belirtmek gerekir ki, dünyada birçok önemli gelişmenin yaşandığı 1970'li yıllarda Kıbrıs, jeostratejik önemine rağmen ABD için en öncelikli konular arasında yer almamıştir.

\section{Bağımsız Cumhuriyet'in Kurulmasından 1974'e kadar ABD’nin Genel Kıbrıs Politikası}

Kıbrıs, hem Batı, hem Doğu ittifakı hem de Bağlantısızlar için Akdeniz'de önemli bir ada olarak görülmüş ve üç kutubun da ilgisine mazhar olmuştur. Bağlantısızlar genellikle hareketin önemli isimlerinden Makarios'u kollamaya çalışırken; NATO, Kıbrıs'ın Doğu Bloğu'na kaymasını engellemeye çalışmıştır. SSCB ise Kıbrı'ın NATO etkisine girmesini istememiş, anlaşmazlıkları NATO'nun güneydoğu kanadını zayıf tutmak için faydalı bir araç olarak görmüş ve adada Türkiye ile Yunanistan'ı anlaşmazlık içerisinde bırakacak düşük yoğunluklu bir krizin varlığını tercih etmiştir. Bu çerçevede Kruschev, Şubat 1964'te NATO'nun adaya barış gücü yerleştirme önerisini reddetmiş ve SSCB'nin bu adaya ilgisiz kalamayacağını ilan etmiştir (New York Times, 1964b).

Aslında NATO üyeleri arasında Kıbrıs'ın Sovyet etki alanına girmesine dair endişe, henüz Kıbrıs Cumhuriyeti (KC) kurulmadan önce ortaya çımıştır. Örneğin İngiliz Koloniyal Ofisi'nin 1957 yılına ait bir belgesinde, Kıbrıs'ın büyük stratejik önemi olduğu ve SSCB'ye yakınlık içerisinde olan bir hükümetin yönetimine geçmemesi gerektiği yazmaktadır. NATO güçlerini arkadan saran, Türkiye'ye oldukça yakın konumda bir Sovyet üssünün, hem NATO hem de Bağdat Paktı'nı zayıflatacağı açıtır (Yakinthou, 2009, s. 71). Birleşik Krallık Başbakanı Sir Anthony Eden de (1955-57) adanın önemini çok açık bir şekilde ortaya koymuştur: "Kıbrıs yoksa petrol arzımızı koruyacak tesisler de yok demektir. Petrolsüzlük ise Ingiltere'de işsizlik ve açlık demektir. Bu kadar basit" (Hakkı, 2007, s. 11) ABD de bağımsız Kıbrıs ortaya çıtığında, adanın jeostratejik öneminin İngiliz üslerine ve İngiltere'nin Orta Doğu ve Akdeniz operasyonlarındaki rolünün sürmesine bağlı olacağını değerlendirmiştir. Adadaki Amerikan radyo iletişim istasyonları ise, Orta Doğu'ya ulaşmak ve oradan istihbarat toplayabilmek 
için bilhassa hayati görülmüştür (OOTH, 2018, ss. 2849-2851). Diğer yandan ABD'nin öncelikli endişesi; adadaki tek iyi organize olmuş parti olarak görülen, SSCB ile yakın olan, işçi örgütlerini kontrol eden ve Kıbrıs Rum oylarının \%30'una sahip olma kapasitesine sahip komünist AKEL'in (Anorhotikov Komma Ergazomenau Laou-Emekçi Halkın İlerici Partisi), ${ }^{2}$ hakim konuma gelmesi olmuştur (OOTH, 2018, 2859). Sovyetler Birliği ve komünist Çin Halk Cumhuriyeti'nin, zayıf bir ekonomiyle başlayan KC'ye ekonomik yardım teklif etmesi de, ABD'nin kaygısını arttırmıştır. Ayrıca belirtmek gerekir ki bu dönem diğer yandan da, hem Türkiye Başbakanı Menderes hem de Yunanistan Başbakanı Karamanlis'in Kıbrıs konusunda desteklenmedikleri taktirde ülkelerinde komünizmin güçleneceği söylemi ile $\mathrm{ABD}^{\prime}$ yi tehdit ettiği dönemdir. ${ }^{3}$

Başlangıçta, Türkiye ve Yunanistan dış işleri bakanları, Soğuk Savaş koşullarının bir ürünü olan KC'nin NATO üyesi olması için teklifte bulunacaklarını bildirseler de (OOTH, 2018, s. 2673) bu durum gerçekleşmemiştir. Şubat 1960 tarihli ABD Milli Güvenlik Konseyi raporunda da, Kıbrıslıların en azından bağımsızlığın ilk yıllarında NATO üyeliğini talep etmeyeceği tahmin edilmiştir. Ancak bu konudaki paragrafın 3 satırının halen sansürlü olması (OOTH, 2018, s. 2866), buna dair bir planın varlığını düşündürtmektedir. Yakinthou'ya göre, KC anayasasında Türkiye ile uyumlu politikalar izleyen Kıbrıslı Türklere, dış politika, güvenlik ve ekonomi konularında anayasal veto hakkı sağlanması da, adanın NATO üyesi olmasa da en azından Sovyetlere kaymaması için bir fren mekanizması olarak düşünülmüsstür (Yakinthou, 2009, s. 71). Bununla birlikte belirtmek gerekir ki, KC NATO yerine Bağlantısızlar Hareketine dahil olurken, Türkiye itirazda bulunmamış, Kıbrıslı Türkler de veto kullanmamıştır.

1974'ta yaşananların ABD kontrolünde gerçekleştiğini en güçlü şekilde savunan isimlerden Constandinos, $A B D$ ve Birleşik Krallık arşivlerinde

\footnotetext{
${ }^{2}$ AKEL, Makarios'u, Kıbrıs Cumhuriyeti Anayasası'nın değiştirilmesi ve bağlantısız dış politika gibi önemli politikalarda desteklemiştir. Bununla birlikte Sovyet yanlısı bir parti olan AKEL, Kıbrıs Cumhuriyeti'ni kuran 1959 Zürih ve London Antlaşmaları'nı, kendi kaderini belirleme hakkına aykırı olduğu için tanımamış; Sovyetlerin itirazına rağmen, NATO üyesi Yunanistan ile birleşmek anlamına gelecek olan ENOSiS'i de desteklemiştir (Tamçelik, 1998, 1-16; Packard, 2008, 365; Güney, 2004, s.30).

3 Örneğin bknz: "Yine de, bu sıkıntılara rağmen, size garanti ederim ki sayın başkan, benim hükümetin görevde olduğu sürece, onlar (Yunan halkı), milli görevlerinden sapmadan ama aynı zamanda Özgür Dünya'nın çıkarlarına hizmet etmeye devam edecektir." (OOTH, 2018, s. 2016).
} 
yaptığı çalışmalar sonucunda, ABD’nin stratejik olarak değerli bulduğu adayı; Yunanistan ve Türkiye arasında bölmek suretiyle NATO kontrolünde tutmak, egemen üs bögelerini ve Amerikan iletişim tesislerini güvence altına almak ve Makaryos'u devre dışı bırakmak istediğini savunmaktadır (Constandinos, 2011, s. 24). Bu argümanın destekçilerine göre, ABD'li siyaset yapıcıları üniter Kıbrıs'ı en kötü senaryo olarak görmüsslerdir. Çünkü bu taktirde adanın, sol eğilimli Makarios tarafından yönetilen, Yugoslavya, Mısır ve Rusya tarafından arka çıkılan ve hali hazırda kuvvetli olan komünist partinin etkisi altına girebilecek bir ülkeye dönüşebileceği düşünülmüştür. 9 Ağustos 1964'te, Makarios'un Türk uçaklarının saldırısına karşı Mısır ve SSCB'den yardım istemesi (Mayes, 1981, s. 178) de bu algıyı kuvvetlendirmiştir. Üstelik bu görüş, sadece yukarıda anılan yazarlar tarafından değil bazı devlet başkanları tarafından da dile getirilmiştir. Örneğin Yugoslavya Devlet Başkanı Tito, Makarios'a karşı darbenin, Kıbrıs'ın Bağlantısızlar Hareketinin önde gelenlerinden birisi olduğu için CIA tarafından organize edildiğini ve amacın adanın Atlantik Paktı'nın etki alanına alınması olduğunu savunmuştur.

1960'larda Makarios'un, Bağlantısızlar Hareketi ve Sovyetlerin desteğiyle, Egemen İngiliz Üslerinin ABD tarafından kullanılmasına müsaade etmediği de düşünüldüğünde, (Tamçelik, 2011, 1528) ABD'nin adayı Türkiye ve Yunanistan arasında bölmeyi ya da en azından bir kısmını, güvenilir NATO üyesi Türkiye'nin kontrolüne vermeyi düşünmüş olması imkansız görünmemektedir. Nitekim ABD Devlet Bakanı Dean Acheson ve yardımcısı George Ball, 1964'te Acheson Planı olarak bilinen belgeyle adaya bir çeşit çifte Enosis ${ }^{4}$ ve NATO çözümü önermiştir. Ball, anılarında hedefi açı bir şekilde dile getirmiştir: "Mesele yeteri kadar açıktı. Kıbrıs stratejik açıdan önemli bir mülk idi ve bizim onu NATO kontrolü altında tutmamız gerekiyordu" 5 (Ball, 1982, s. 342). Bununla birlikte, ileriki bölümlerde

\footnotetext{
${ }^{4}$ incelenen $A B D$ belgelerinde taksim (partition) yerine çifte enosis terimi tercih edildiğinden, bu çalışma da aynı terimi kullanmaktadır. Örneğin Sisco, 1971'de Kissinger'a Kıbrıs sorununu özetlerken Acheson planından bir çeşit çifte enosis planı olarak bahsetmiştir. Terim, adanın Türkiye ve Yunanistan arasında paylaşılması anlamında kullanılır. (OOTH, 2007a, s. 913).

${ }^{5}$ Bir başka belgeye göre Ball, enosise olumlu yaklaşmış ve bunun adanın NATO hükümeti tarafından yönetileceği anlamına geleceğini ancak Türkiye'nin rızası için O’na bazı toprak tavizleri verilmesi gerektiğini söylemiştir. (Wenzke ve Lindley, 2011, s. 22).
} 
anlatılacağı üzere, bu mantıksal çıkarımın 1974'te uygulandığını kanıtlayabilecek yeteri kadar belge mevcut olmadığı gibi dönemin yöneticileri de böyle bir hedefin varlığını reddetmektedir.

\section{ABD'nin Makarios'un Devrilmesini İstediğine Dair Argümanlar}

Dönemin ABD Dış İşleri Bakanı Kissinger, Kıbrıs'taki krizi, başkan Nixon ile kendisinin, belirsiz jeopolitik sebeplerle, Türkiye ile danışıklı döğüş içerisinde, Makarios'u devirmek için çıkardığına yönelik bir mit yaratılmasından şikayet etmektedir. Kissinger, Makarios'un politikalarının bazı kısımları hakkında çekinceleri olduğunu kabul etmekle beraber, bunların görece küçük rahatsızlıklar olduğunu ve düşük önceliğe sahip olduklarını savunmaktadır. Kissinger'a göre özellikle de Nixon'un başkanlığındaki karmaşık son ayda, isteyecekleri en son şey, iki NATO müttefiği arasındaki bir savaş ve uzak stratejik bir adada etnik çatışmadır (Kissinger, 2000, ss. 495-496). Dolayısıyla ona göre ABD yönetiminin, bir darbe ile Makarios'un devrilmesi konusunda Yunan cuntasını desteklemiş olması mümkün değildir.

Söz konusu argümanı tartışmaya öncelikle, Kissinger'in Yunanistan'daki cunta ile ilişkilerini Atina Büyükelçisi Henry J. Tasca'dan ziyade Atina'daki CIA ofisi vasıtasıyla yürüttügünü belirterek başlamak gerekir (Stern, 1975, s. 51). Nitekim, dönemin Atina'daki CIA şefi Richard S. Welch, CIA'in Yunan Halkı'na karşı işlediği suçları gerekçe gösteren bir grup tarafından 1975'te öldürülmüştür (New York Times, 1976). Cunta lideri Ioannides'in de 1964 'te Kıbrıs'ta istihbarat subaylığı yaptığının ve Yunanistan'daki CIA şefiyle yakın ilişkiler kurduğunun bilinmesinde fayda vardır (Mayes, 2000, s. 230). İlaveten, 1973'de Yunanistan'da ikinci darbeyi yapan ve Kıbrıs'taki darbeyi organize eden cunta yöneticilerinin çoğunluğu daha önce Kıbrıs'ta görev yapmış ve adayı iyi tanıyan isimlerdir.

Ioannides'in devrildikten sonra eski rütbeli meslektaşlarına, "benim bildiklerimi bilseydiniz ve darbeden önce bana verilen garantiler size de verilseydi, aynen benim yaptı̆̆ımı yapardınız" (Stern, 1975, s. 51) demesi, ABD'nin darbedeki rolüne dair argümanları güçlendirmiştir. General ayrıca kendisine CIA aracılığıyla $\mathrm{ABD}$ 'nin arkasında olduğu güvencesinin verildiğini de iddia etmiştir (Constandinos, 2009, s. 158). 1986'da yazdığ Gerçek başlıklı 
hatıratında, dönemin Yunanistan Genel Kurmay Başkanı General Bonanos da, Nixon-Kissinger yönetimi ile Cunta arasında aracılık/bağlantı görevi verilen Yunan kökenli eski büyükelçi Thomas A. Pappas'ın, Makarios'un devrilmesi konusunda $\mathrm{ABD}$ onay ve desteğini kendisine ilettiğini yazmaktadır (Hitchens, 2002, s. 71; Kutler, 1990, s. 652). Nixon'un seçim kampanyasına Cunta'nın Pappas aracılığıyla para transfer ettiğinin, bizzat Tasca tarafından kabul edilmesi, ${ }^{6}$ iddiaların inandırıcılığını arttıran başka bir faktör olmuştur.

Kıbrıs'ın Rum Cumhurbaşkanı Başpiskopos Makarios siyasi hayatı boyunca merkezin solunda bir tutum sergilemiş ${ }^{7}$, NATO'ya karşı mesafeli durmuş ve Bağlantısızlar Hareketi'ne katılmanın yanında sadece Sovyetler Birliği ile değil, Yugoslavya ve diğer Doğu Avrupa ülkeleri ile de iyi ilişkiler geliştirmiştir. Makarios'un içeride de, Küba' daki Castro Hareketi ile kıyaslanan komünist AKEL partisinin desteğini almış olması, Batılı liderlerin kendisine şüphe ile bakmasına neden olmuştur.

Aslında Makarios, 1962'de yaptığı ABD ziyaretinde havaalanında bizzat Başkan John F. Kennedy tarafından oldukça sıcak bir şekilde karşılanmış ve övgüye mashar olmuştur (John F. Kennedy). Ancak ardından Kuzey Vietnam'daki Hanoi hükümetine silah sağladığının ortaya çıkmasıyla birlikte, ABD'nin 1966'da bir yıl boyunca Kıbrıs'a yardımlarını durdurduğu da bilmek gerekir (Uzer, 2010, s. 126; O’Malley ve Craig, 1999, s. 132).

Yıkarıda anlatılanlara rağmen Makarios'u, komünizm sempatizanı olarak resmetmektense; oldukça kritik bir lokasyonda bulunan küçük ülkesini bağımsız tutabilmek için stratejik hareket etmek zorunda kalan bir lider olarak tanımlamak daha doğru olacaktır. Makarios, oldukça saygı duyduğu Tito'yu kısmen hatırlatır şekilde, iki kutubu birbirine karşı oynamaya çalışmıştır. ${ }^{8} \mathrm{O}^{\prime}$ Malley ve Craig de, Makarios'un komünist olmadığını, aksine kariyerine komünistlere karşı kilisenin etkisini arttırmaya çalışarak başladığını ve Yunan Cuntası ile ilişki içerisindeki sağın ona

\footnotetext{
${ }^{6}$ Pappas'ın kendisi de, "yardımama ihtiyaç olan her zaman CIA ile çalıştım" demiştir. (Kutler, 1990, s. 208, 651).

7 Makarios'un onaylı biyografi yazarı eski Kıbrıs büyükelçisi Vanezis, din adamları arasında bunun çok alışıldık dışı olmadığını yazmaktadır. (Vanezis, 1979, s. 67).

${ }^{8}$ Nitekim Washington'un temel rahatsızlıklarından bir tanesi Makaryos'un Doğu'yu Batı'ya karşı oynama eğilimi olmuştur. (Constandinos, 2009, s. 63).
} 
karşı olması nedeniyle sola dayanmak zorunda kaldığını savunmaktadır. (O'Malley ve Craig, 1999, s. 132) Mallinson da, Makarios'un yanlış bir şekilde komünist yanlısı olarak değerlendirildiğini, halbuki Makarios'un yaptığının ülkenin bütünlüğünü koruyabilmek adına orta yolda kalabilmek için hünerli bir diplomasi uygulamaktan ibaret olduğunu savunmaktadir (Mallinson, 2011, s. 1). Nitekim Makarios, Ekim 1970'te Nixon ve Kissinger ile görüştüğü $\mathrm{ABD}$ ziyaretinde, Bağlantısızlar Hareketi'nin üyesi olmakla birlikte Kıbrıs'ın Batı yanlısı olduğunu ve asla Küba olamayacağını ki bunun da kısmen Kıbrıslıların oldukça dindar olmalarından kaynaklandığını söylemiştir. Ayrıca sol kanattan kimseyi yönetimde kritik bir pozisyona atamadığını ve solcuların kendisini destekleme nedenlerinin daha iyi alternatiflerinin olmaması, kendisinin desteği kabul etme sebebinin ise onları kontrol altında tutabilmek olduğunu savunmuştur (Constandinos, 2009, ss 81-82). 1973 tarihli Să̆a Doğru Yaklaşımda Bulunmak başlıklı CIA raporunda da, Makarios'un son zamanda sağ ile diyalog başlatma eğiliminde olduğu ve iki ayrı merkez Rum partisini birleşmeye davet etmeyi planladığı tespit edilmiştir (OOTH, 2007b, s. 251). Üstelik Makarios Mayıs 1974'te SSCB ile ciddi bir diplomatik ayrılık yaşayan Çin'i ziyaret ederek Sovyet kontrolünde olmadığını da göstermiştir (Constandinos, 2009, s. 372).

Aslında Makarios, Yunanistan yönetimleri ile daha önce de sorunlar yaşamıştır ancak Kıbrıs'taki darbeye giden süreç esasen Yunanistan'daki darbe ile başlamıştır. 1967 Nisan'ında Yunanistan'da cuntanın yönetimi ele geçirmesi, Kıbrıs'ta çatışmaların tekrar hızlanması ve Türkiye'nin müdahale edeceğine yönelik tehditlerinin ardından Makarios, AKEL ile birlikte, Enosis'i "arzulanan ancak yakın vadede mümkün olmayan bir ideal" olarak görmeye başlayıp hedeflerinin arasından çıkartmıştır. Buna rağmen 1968 Cumhurbaşkanlığı seçimlerinde \%96.26 (Presidential Elections, 2018) oy almayı başararak Rumların gözündeki meşruiyetini kanıtlayan Makarios'un kararı, kısa vadede Enosis isteyen EOKA'cllar ve Yunan Cuntası için bir engel olarak görülmesine neden olmuştur. Mart 1969'da oluşturulan Milli Cephe, (Ethnikon Metopon) Makarios'u vatana ihanetle suçlamaya başlamış ve suikast girişimleri üst üste gelmeye başlamıştır. Bunlardan en bilineni 8 Mart 1970'de Makarios'un helikopterine yapılan (Washington Post, 1977) ve bir numaralı zanlı eski EOKA'cı ve İç İşleri Bakanı 
Georgadjis'in yargılanamadan ölü bulunduğu vakadır. Ancak suikast girişimlerinde $A B D^{\prime}$ nin rolü olduğunu savunmak güçtür. Çünkü ABD Büyükelçiliği yetkilileri, suikast girişimleri olabileceği ve önlem alınması gerektiği yönünde Makarios'u birden çok kez uyarmıştır (Asmussen, 2008, s. 17; Constandinos, 2009, s. 155).

Bu dönemde Cunta, Makarios'a karşı mücadelesinde Batı'nın desteğini alabilmek için O'nun komünist olduğuna dair propoganda yapmıştır. Grivas'in 1971'de adaya geri dönüp EOKA-B'yi kurması ve Makarios'u tehdit etmesi neticesinde Makarios, Doğu Bloğu ülkesi olan Çekoslovakya'dan 1972'de gizlice silah almıştır. Bu hareket başpiskoposun komünist imajını güçlendirmiştir. Bu silahlara, Kıbrıslı Türklere karşı kullanılmasından endişe eden Türkiye'den fazla tepkiyi Yunanistan göstermiştir. Silahlar ile ilgili anlaşmazlığın Kıbrıs'taki BM Barış Gücü şemsiyesinde çözülmesi başarılmışsa da (OOTH, 2007a, s. 1011), artık hem Türk hem de Yunan hükümetinin Makarios aleyhine çalışıyor olması, Washington Özel Eylemler Grubu (WSAG) toplantısına katılan Amerikalı Amiral Moorer tarafından trajikomik bir şekilde dile getirilmiştir: "Bana öyle geliyor ki ilk defa Yunanistan ve Türkiye birlikte çalışıyor ve biz bundan mutsuzuz" (OOTH, 2007a, s. 980).

Gerçekte Türkiye ve Yunanistan'daki cuntanın çifte Enosis üzerine anlaşmasının, adanın NATO çemberine girmesi açısından ABD'nin çıkarlarına uyduğu ancak Makarios'un burada önemli bir engel olarak durduğu üzerine tartışmalar yapıldığı dayanaksız bir komplo teorisi değildir. Örneğin 1971 Ağustos'unda yapılan Kıdemli Grup Değerlendirme Toplantısı'nda (Senior Review Group Meeting-SRGM) Makarios'un Yunanistan ve Türkiye'nin birlikte hareket edip ona bir çözüm empoze etmesinden endişe ettiği ve bu yüzden Moskova'yı ziyarete gittiği konuşulmuştur (OOTH, 2007a, s. 913). Mart 1972'de Tasca'dan ABD Dış İşleri Bakanlığına gelen telgrafta, "temel çıkarımız Yunanistan ve Türkiye arasındaki dost ilişkileri güçlendirmektir, eğer Makarios sıkı durur, direnir ve Türkiye ile Yunanistan'ın hedeflerini sekteye uğratırsa, bu bizim çıkarımıza olmaz" denmiştir (OOTH, 2007a, s. 1017). Sovyet Büyükelçiliği Konsolosu Vorontsov da, Bakan Yardımcısı Davies'e 18 Mart 1974'te verdiği belgede, Ankara ile Yunanistan'ın Kıbrıs hükümeti ve halklarının iradeleri dışında bir çözüm için gizli müzakereler yaptığını iddia etmiştir (The National Archives, 2018) 
Arşivlerden ABD'li yetkililerin zaman zaman Makarios'suz bir çözümü tartıştığı ancak bunun olumlu ya da olumsuz sonuçları üzerine uzlaşamadığı anlaşılmaktadır (OOTH, 2007a, s. 1028). ABD'li yetkililerin Makarios ile ilgili olumsuz söylemleri olduğu da doğrudur. Sadece üç örnek vermek gerekirse; Ball hatıralarında "rahip elbisesindeki kurt" olarak resmettiği Makarios'un Moskova ile flörtünün, Sovyetlerin stratejik Akdeniz'e dahil olması tehdidini getirdiğini yazmıştır (Ball, 1982, s. 338). ABD'nin o dönemki BM Daimi Büyükelçisi de, kötü ve güvenilmez olarak tanımladığı Makarios için, "onunla başetmenin tek yolunun o eski alçă̆a hayatı dar etmek" olduğunu söylemiştir. (Ball, 1982, ss. 340-341) Yakın Doğu ve Güney Asya İşleri Bakan Yardımcısı Sisco da, Makarios için "şeytan papaz" demiştir (OOTH, 2007a, s. 914).

Yukarıda anlatılanlara rağmen, ABD'nin Makarios'suz ya da Kıbrıslıların iradeleri dışında bir çözümü desteklediğine dair bir belgeye ulaşılamadığını belirtmek gerekir. Örneğin Sisco'nun Bakan Rogers'a gönderdiği memorandumda, uzun süredir Türkiye'nin tercih ettiği çifte enosis çözümünün zaman zaman Yunan hükümetince de desteklendiği yazmaktadır. Ancak Makarios ve Kıbrıslı Rumların kati sürette buna karşı çıtı̆̆ 1 ve Türkiye ve Yunanistan'ın yerine çifte enosis üzerine anlaşıp Kibrislilara empoze etmesi durumunda, Makarios'un BM'nin ve hatta Sovyetlerin de dahil olabileceği bir kriz çıartabileceği değerlendirilmiştir. Nihayetinde ABD'nin politikasının ancak Kıbrıslıların uzlaşacağı bir çözümü kabul etmek olması gerektiği sonucuna varılmıştır (OOTH, 2007a, ss. 894-895). Aynı yıl ABD Dış İşleri Bakanlığı'ndan Ankara Büyükelçiliğine gönderilen telgrafta, çifte Enosisin sakıncaları nedeniyle ABD hükümetinin çıarına olmadığı ve bu ihtimali engellemek gerektiği konusunda fikir birliği teyit edilmiştir. Tavsiye edilen ise, yine toplumlararası görüşmeleri desteklemek olmuştur (OOTH, 2007a, ss. 989999). Ayrıca bu toplantılarda, Kıbrıslılar arasında silahlar çekildiği anda Yunanlıların Türkiye ile işbirliğini bırakıp Rum kardeşlerini destekleyeceklerinin değerlendirildiği anlaşılmaktadır (OOTH, 2007a, ss. 914-915). Dolayısıyısla Türkiye ve cunta yönetiminin Kıbrıs üzerine uzlaşması, ABD tarafından da pek mümkün görülmemiştir. 


\section{ABD'nin, Makarios'un Göreve Dönmesini İstemediğine Dair Argü- manlar}

ABD yönetimine yönelik bir diğer eleştiri, seçilmiş başkan Makarios'un göreve dönmesi için çaba göstermemiş olmasıdır. Nitekim darbenin ertesi günü ABD hükümetinin basın sözcüsü "Makarios hükümeti, bizim için Kıbrıs hükümeti midir?" şeklindeki soruya, "bu konuda hiç yorum yapmamayı tercih ediyorum" şeklinde cevap vermiştir. Bundan bir gün sonra, "ABD'nin görüşü Makarios'a karşı dışarıdan bir müdahale yapıldı̆̆ı mıdır?" şeklinde soruya da, "hayır, bizim görüşümüze göre dışarıdan bir müdahale yoktur" denmiştir. Ardından Kissinger'in pazartesi günü Makarios ile sıradan vatandaş mı, başpsikopos mu yoksa devlet başkanı olarak mı görüşeceği sorusuna ise, "Başpiskopos Makarios ile görüşecek" denmiştir (Stern, 1975, s. 60; Hitschens, 2002, s. 167). Kissinger bir diğer basın toplantısı için sözcüsünden, mümkünse Makarios hakkında bir şey dememesini ve Kıbrıs'ın toprak bütünlüğüne dair standart söylemi kullanmasını istemiştir (OOTH, 2007b, s. 316). Sözcü de gerçekten Makarios'a dair hiçbir şey söylememiştir. Diğer yandan ABD, BM Güvenlik Konseyi'nin Yunanistan'ın darbede oynadığı rolünü kınayan taslak kararını veto etmiştir (Mirbargheri, 1998, s. 111). Tüm Avrupa hükümetleri, yeni Cumhurbaşkanı ve eski EOKA mensubu Nikos Sampson'a parya muamalesi yaparken ve Makarios'un durumu henüz bilinmezken, Kissinger'in Lefkoşa'daki ABD elçisine, Sampson'un dış işleri bakanını resmi ünvanıyla kabul etmesi emri verdiğini de gözden kaçırmamak gerekir. Aslında bu hareketle, darbe hükümetini de-facto tanıyan ilk ve tek devlet ABD olmuştur (Hitchens, 2002, s. 166).

Öncelikle, darbeden sonra Kissinger ve Nixon arasında geçen telefon konuşmasında, iki ismin olanlardan sorumlu tutulamayacakları ve Makarios'u bu olaydan korumak için hiç bir şans ve imkanlarının olmadığı konusunda uzlaştıkları anlaşılmaktadır (OOTH, 2007b, s. 339). Arşiv belgelerinden de görülmektedir ki, Makarios'un darbe sonrası destekçileriyle birlikte direnmektense adayı terketmesi üst yönetimde şaşkınlıkla karşılanmıştır. Örneğin darbenin ertesi günü yapılan WSAG toplantısında Kissinger, Makarios'un adayı terketmesinin çıkarına olmadığını ve neden 
adada kalmadığını bir türlü anlayamadığını söylemiştir. Boyat da cevaben, "bu hareket hiç onluk değil, Makarios cesurdur, ben de anlayamıyorum" demiştir (OOTH, 2007b, s. 293).

ABD'nin darbe sonrası Makarios'a yönelik politikası genel olarak sonraki politikalarında kendisini bağlayabilecek belirgin bir açıklamada bulunmamak ve olayların seyrini izlemek şeklinde olmuştur. Bunda üst yönetimin Makarios'u geri getirmenin sonuçları konusunda emin olamaması, asli nedendir. Kissinger'e gelen istihbarat raporlarına göre, Makarios'un, darbenin arkasından kısa süre içerisinde Kıbrıs'a dönmek istemesi, tekrar bir iç savaşa neden olacağı gerekçesiyle sol kesim haricindeki tüm Kıbrıslı kesimlerce endişe ile karşılanmıştır. Üstelik Sampson'un istifası sonrası Kıbrıs Hükümetinin başına geçmiş olan Klerides de açık bir şekilde, Makarios'un yakın bir tarihte dönüşünün felaket yaratacağını ve ABD'nin bunu engellemek için elinden geleni yapması gerektiğini savunmuştur (OOTH, 2007b, s. 403). Dolayısıyla Makarios'un dönüşü konusundaki kafa karışıklığı sadece ABD'li yöneticilere has olmamıştır.

Yukarıdaki endişelere ilaveten Kissinger, onu geri getirmenin kesin bir yolunu bulmadıkça, Makarios'un arkasında net bir şekilde durmanın, diğer aktörleri de aynı yönde teşvik etmesinden sakınmıştır. Makarios'u geri getirme iddiasıla Türkiye'nin müdahale etmekte kendini daha haklı görebilecek olması, bakanı özellikle endişelendirmiştir (OOTH, 2007b, s. 318). Nitekim 17 Temmuz'da Ecevit'in, Makarios'un 24 saat içinde göreve döndürülmemesi durumunda Kıbrıs'a müdahale edeceğini bildirmesiyle durum daha da karmaşıklaşmıştır. ${ }^{9}$ Yine de Kissinger, Türkiye ve Yunanistan'ın uzlaşması halinde Makarios'a bir itirazının olmadığını söylemiştir (OOTH, 2007b, s. 398). Nitekim sonrasında "biz Makarios'a karşı değiliz, sadece taraflardan birini tutuyor gözükmekten kaçınıyoruz" demiştir (OOTH, 2007b, s. 316).

Birleşik Krallık Dış İşleri Bakanı Callaghan, kamuoyundan gördüğü baskı nedeniyle Makarios'un göreve dönüşüne daha sıcak bakmıştır. Ancak Kissinger'in Callaghan ile görüşbirliği içerisinde olduğu nokta (OOTH, 2007b, s. 320) 18 Temmuz tarihli bir telegrafta açığa çıkmıştır:

\footnotetext{
${ }^{9}$ Kissinger Türkiye'nin, tarihi düşman ve Kıbrıslı Türklerin çektiği sıkıntıların sebebi olarak gördüğü Makarios’u geri getirmek için askeri güç kullanacağı fikrini şaşkınlıkla karşılamış ve inandırıcı bulmamıştır. (Kissinger, 2000, s. 495).
} 
“Ĕger BM Makarios'un pozisyonunu meşrulaştırır ve yaptırımlarla desteklenecek şekilde Makarios'un göreve iadesi yönünde karar çıkartırsa ve Batı da bu askeri sorumluluktan kaçınırsa, o zaman Sovyetler bu boşluğu doldurmaktan çekinmeyecektir." (OOTH, 2007b, s. 322). Nitekim SSCB temsilcisi BMGK toplantısında, Yunanistan hükümetinin darbenin tüm muhtemel sonuçlarına karşı hazır olması gerektiğini (BMGK, 1974) ilan etmiştir. Anlaşılacağı üzere, Sovyetlerin etki alanını Kıbrıs'a doğru genişletmesine yönelik geleneksel endişe, Makarios'un dönmesi konusunda da belirleyici olmuştur.

\section{ABD'nin, Adadaki Üs ve Tesisler Nedeniyle Darbeyi Desteklediğine Dair Argümanlar}

Adadaki üsler ve tesisler ABD için her zaman önemli olmuştur. İngiliz Üslerinin, bilinen Soğuk Savaş amaçları çerçevesinde Ortadoğu ve Sovyetler Birliği'nin dışında Türkiye ve Yunanistan'ı izlemek için de kullanıldığını belirtmek gerekir ${ }^{10}$ (Mallinson, 2011, ss. 737-752). ABD'nin Lefkoşa Büyükelçisi Grant de, ABD'ye ait tesislerin bölgedeki ülkelerin radyo yayınların takip ve rapor etmekle görevli olduğunu beyan etmiştir (Wenske ve Lindley, 2011, s. 28).

Adadaki üs ve tesislerin önemini arttıran gelişmelerden bir tanesi, füze nitelik ve niceliğine dair rekabette, 1975 'te Sovyetlerin öne geçmesidir. Nihayetinde ABD için, Sovyetlerdeki teknolojik gelişmeleri gözetleyebilmek, konuşmaları dinleyebilmek ve füze fırlatma testlerini izleyebilmek açısından bölgeye yakın üsler daha önemli hale gelmiştir. O’Malley ve Craig, Stockholm International Peace Research Institute verilerine dayanarak Kıbrıs'taki gelişmiş radarların konum itibariyle, Sovyetlerdeki testleri Türkiye ve İran'dakine oranla daha iyi ve erken tespit edebildiğini ortaya koymuşlardır. Buna, 1973 Yom Kippur Savaşı'nda İngiltere'nin, Kıbrıs'taki üslerini $\mathrm{ABD}^{\prime}$ ye kullandırtmaması ve hatta bunları Kıbrıs'a terketme niyetini ilan etmesi eklenirse, (Mallinson, 2009, ss. 737-752; O'Malley ve Craig, 1999, ss. 140-145, 150) ABD'nin adanın dost NATO ülkelerince paylaşılmasını istemiş olabileceği mantıksız gözükmemektedir.

\footnotetext{
${ }^{10} \mathrm{Her}$ ne kadar belgede Kıbrıs'ı ilgilendiren konularda denmişse de, Kıbrıs'ı ilgilendiren konuların tespiti için nihayetinde tüm konuların dinlenmesi germektedir.
} 
Aslında 1959 'da KC kurulma aşamasındayken yazılan ABD raporlarında, yeni cumhuriyette dinleme tesislerinin tehdit altında olmayacağ 1 değerlendirilmiştir (OOTH, 2018, s. 2773). 1960'ların sonundan itibaren ise raporlar çoğunlukla, Yunanistan'daki üslerin öneminin arttığı ve bu yüzden ABD'nin Yunanistan ile olumsuz ilişkiler geliştirmemesi gerektiği yönündedir. Örneğin 1971'de Davis'ten Sisco'ya gönderilen memorandumda, artık Kıbrıs'taki üslerin ABD için hayati önemde olmadığ savunulmuştur. Buna göre, 6. Filonun Sovyet Filosuna karşı kendi saldırı ve savunma yetenekleri vardır ve NATO'nun, Kıbrıs vasitasıyla Sovyetlere karşı yapabileceği herhangi bir şeyi, ABD güçlerinin hali hazırda var olduğu İncirlik, Çiğli ya da Atina'dan da gerçekleştirebilmesi mümkündür (Wenske ve Lindley, 2011). Yine de ABD doğal olarak seçeneklerini mümkün olduğunca fazla tutmaya çalışmıştır. Ancak 1968'te Kıbrıs hükümeti ile yapılan anlaşma neticesinde Makarios'un, yüksek gelir elde ettiği bu tesislerin süresini 10 yıl daha uzatmayı kabul ettiğini, üstelik bu paraya çok ihtiyacı olduğunu belirtmek gerekir (Washington Post, 1977; Constandinos, 2009, ss. 81-82). Dolayısıyla üzerinde uzlaşılmış bir anlaşma varken, sonunun nereye varacağ mel tehlikeli bir darbe girişimine ABD'nin destek olması, en azından tesisler çerçevesinde mantıklı gözükmemektedir. Nihayetinde Brezhnev, Nisan 1974'te, Kıbrıs hükümetinin devrilmesine tepkisiz kalamayacaklarını açıç̧a ilan etmiştir (The National Archives, 2018).

\section{ABD'nin Yunanistan'a Askeri Yardımları Kesmemesine Dair Argü- manlar}

ABD'nin Kıbrıs konusunda Yunan Cuntası ile işbirliği içerisinde olduğuna dair iddiaların bir diğer kaynağı da ağır insan hakları ihlalleri ve darbeye rağmen askeri yardımlarını kesmemiş olmasıdır. Aslında Nisan 1967'deki darbe sonucunda ABD, Yunanistan'a \$52.6 milyonluk askeri yardımı dondurmuşsa da bazı kalemlerin ve yedek parçaların hibesine devam etmiştir. Nitekim Başkan Johnson için hazırlanan memorandumda, ABD'nin Yunanistan'ın demokrasiye dönmesine yönelik baskısının gerçekten ziyade sembolik olduğu kabul edilmektedir. Yöne- 
tim, ABD-Yunan ittifağını riske atmamak için tercihini, sert önlemler yerine kısmi bir askeri yardım kesintisi ve düşük düzeyde baskı yapmaktan yana kullanmıştır (OOTH, 2007a, s. 656).

Yunanistan, ABD ve NATO'ya bazı askeri kolaylıklar sağlamıştır ki bunlara 6. Filo için iletişim ve lojistik sağlamak da dahildir. Ayrıca, Amerika'nın Sesi'nin (VOA) Arap ve Doğu Avrupa yayınları için Yunanistan'daki röle istasyonlarına ciddi bir bağımlılık söz konusudur. ABD Savunma Bakanlığı'nın bir kısmı halen sansürlü olan değerlendirmesinde de, hali hazırda sıkıntılı olan Libya ve Türkiye'deki üslerdeki kısıtlamalar arttı̆̆1 taktirde, Ortadoğu hedefleri için Yunanistan'dan daha uygun üs bulunmadığ 1 yazılmaktadır (OOTH, 2007a, s. 657). Üstelik 1970'de Libya'daki Wheelus üssünün kaybından sonra Yunanistan'ın önemi daha da artmıştır (OOTH, 2007a, s. 694). Bu çerçevede Kissinger, Nixon için hazırladığ 1 güvenlik raporunda, askeri yardımların kesilmesi durumunda cuntanın yabancılaşabileceğini ve üslerin kaybedilebileceğini ortaya koymuştur. Nihayetinde belgeye göre askeri yardımların ana sebebi bu üslerin kullanım hakkıdır (OOTH, 2007a, ss. 669-671). Dolayısıyla, ABD'nin cuntanın tüm anti-demokratik uygulamalarına rağmen yardımlarını kesmemesi, Kıbrıs konusundaki desteğinden ya da siyasi memnuniyetinden ziyade, Yunanistan'ı ve bu üsleri kaybetme korkusundan kaynaklanmıştır.

\section{ABD'nin Güç Kullanmamasının Durumdan Memnuniyetini Gösterdi- ğine Dair Argümanlar}

ABD'ye yönelik bir diğer eleştiri, 1974'teki darbeyi ve Türkiye'nin müdahalesini durdurmak için güç kullanmayı reddetmesine yöneliktir. Daha önce anılan ve yaşananları komplo olarak gören yazarlar, ABD'nin bu önlemi almamasını, durumdan memnun olmasıyla bağdaştırmıştır. Halbuki yeni cumhuriyet kurulduğundan beri ABD'nin Kıbrıs üzerine en istikrarlı politikası, Türk-Yunan savaşını her ne pahasına olursa olsun engellemek ve soruna güç kullanmadan diplomatik yöntemlerle çözüm bulmak olmuştur.

1967'deki krizde Rusk, tüm ilgili büyükelçiliklere gönderdiği telgrafta, “konu o kadar önemli ki, ikili ilişkilerimizin geleceğgi, Yunanistan ve Türkiye ara- 
sindaki düşmanlığı önlemeye göre ikincil önemdedir. Türkiye ve Yunanistan arasındaki barış, ABD ulusal çıkarları çerçevesinde, Kıbrıs'taki meselelerden daha önemlidir." Demiştir (Wenske ve Lindley, 2011, ss. 34-35). Türkiye ile Yunanistan arasındaki bir savaşı engellemek, 67'de olduğu gibi 1974'te de ABD için temel amaç olmaya devam etmiştir. ABD'de darbeden bir kaç hafta önce hazırlanan istihbarat raporunda; Türk-Yunan çatışmasının; NATO içi ilişkilere zarar vereceği, NATO ile Varşova Paktı arasındaki askeri dengeyi bozacağ1, iki ülkenin belkemiğini oluşturduğu müşterek askeri planlamaları uygulanamaz hale getireceği ve güneydoğu kanadındaki savunma hattını çökerteceği değerlendirilmiştir. Üstelik böyle bir çatışmada, iki tarafın da karşı tarafı saldırgan gösterip, ABD'den kendi lehine güç kullanmasını talep edeceği düşünülmüştür. İki ülkede de ABD askerinin varlığı bu işi daha da içinde çıkılmaz hale getirecektir (OOTH, 2007b, ss. 75-76). Bu çerçevede Ankara Büyükelçiliği'nden gönderilen telgrafta, Türk-Yunan çatışmasını engellemenin Kıbrıslı Rumlar arasındaki iç savaşı engellemekten bile daha önemli olduğu değerlendirmesi yapilmıştır (OOTH, 2007b, ss. 287-288).

Arşivler ve siyaset uygulamalarının gösterdiği bir başka şey de, ABD'nin daha en başından beri Kıbrıs sorununa askeri anlamda müdahil olmamak yönünde karar aldığıdır. ABD yönetimi sadece 1974'te değil; 1963, 1964 ve 67 çatışmaları sırasında da askeri önlem almaktansa taraflara önemli isimleri arabulucu olarak göndermeyi tercih etmiştir. ABD 25 Ocak 1964'te, bir Amerikan alayını da içeren geniş tabanlı NATO güçlerinin barışı sağlamak için adaya gelmesine yönelik İngiliz önerisini de reddetmiştir (Ball, 1982, s. 340). Askerlerinin iyi silahlanmış Rum paramiliterlerce saldırıya uğramasından endişe eden (CIA, 1964) Johnson, kendi deyimiyle kabile savaşını durdurmak için yeteri kadar ileri gittiklerini, artık önlerinde sadece $\mathrm{BM}$ yoluyla çalışmak kaldığını söylemiştir. Bununla birlikte $\mathrm{ABD}, \mathrm{BM}$ gücü kurulmasına yönelik BMGK tartışmalarında, Sovyetleri mümkün olduğunca uzak tutmaya çalışmıştır (Ball, 1982, s. 348). Dolay1sıyla ABD'nin 1974'teki politikasının önceki politikalarıyla çeliştiğini ya da istikrarsız olduğunu iddia etmek güçtür.

BMGK'nın 4 Mart 1964 tarihli kararı ile BM Barış Gücü, Mart ayı sonunda adaya yerleşmeye başlamıştır. Barış Gücü'nün etkisiz kalması ve çatışmaların tekrar yoğunlaşması üzerine Türkiye adaya müdahale kararı 
aldığında, Johnson yine diplomasiye başvurmuş ve nezaketsiz bir mektupla Türkiye'yi engellemiştir. Ball'ın atom bombasının diplomatik eşdeğeri (Ball, 1982, s. 350), Kissinger'in ise büyük hata (Kissinger, 1981, s. 201) olarak tanımladığı ve muhtemelen Johnson'un kaleme almadığ (Hare, 1987) mektup sonrasında ortaya çıkan kızgınlık, Türkiye'yi ABD'den uzaklaştırmıştır. Moskova ise mektuptan sonra oluşan çatlaktan faydalanabilmek amacıyla desteğini Lefkoşa'dan Ankara'ya doğru kaydırmaya başlamış ve Türk-Sovyet ilişkileri gelişme yoluna girmiştir (Constandinos, 2009, s. 67).

$\mathrm{ABD}$, ilginçtir ki, Kıbrıs sorunun taraflarını güç kullanmakla değil, güç kullanmamakla tehdit etmiştir. ABD'nin, Johnson Mektubu'nda Türkiye'yi Sovyet saldırısına karşı korumamakla tehdit ettiği iyi bilinmektedir. Bununla birlikte aslında Makarios'un da; zalim ve acımasız davranışlarını sürdürdüğü taktirde, Türkiye'nin kaçınılmaz şekilde işgale girişeceği ve ABD'nin buna engel olmak için parmağını bile kıpırdatmayacağı konusunda uyarıldığı pek bilinmez ${ }^{11}$. Üstelik ABD, mektubun hemen ardından Papandreu'ya da, Türk müdahalesinin, başkanın güçlü müdahalesi sayesinde engellendiğini, ama eğer Yunanistan daha uzlaşmacı olmazsa ABD'nin bir dahakine bu kadar sert bir tedbir almayacağını söyleyerek benzer bir göz dağı vermiştir (Ball, 1982, s. 353). Bir başka ifadeyle ABD, kendisi güç kullanma tehdidinde bulunmamış ancak Türkiye'yi Sovyetlerin, Yunanistan ve Kıbrıs Cumhuriyeti'ni ise Türkiye'nin güç kullanmasına karşı tepkisiz kalmakla tehdit etmiştir. ABD dönem dönem bu teditleri tekrarlamıştır.

1967'de çatışmaların tekrar yoğunlaşması üzerine Türkiye bir kez daha müdahale kararı aldığında, mektup sonrası gelişen ilişkilerin de katkısıyla Sovyetler Birliği bu sefer 1963-64'teki kadar karşıt gözükmemiştir. Nihayetinde enosis hedefleyen Yunanistan bu tarihten itibaren anti-komünist faşist bir cunta tarafından yönetilmektedir. Üstelik Kıbrıs'taki Grivas da katı bir anti-komünisttir (Mallinson, 2011, s. 7). Bu nedenle ABD, Sovyetler üzerinden tehdidin bu sefer işe yaramayacağın düşünmüş ve temsilcisi Cyrus Vance'ı bölgeye göndermiştir.

Başarılı bir diplomasiyle Yunan askerlerinin ve Grivas'ın adadan gönderilmesini sağlayan Vance yıllar sonraki bir söyleşisinde, hayatındaki en ${ }^{11}$ Ball bu tehdit üstüne, "Her ne kadar makarios bozuntusunu belli etmemeye çalıştıysa da, odadan
çıktığımızda sakallarının bile solduğunu hissettim" demiştir (Ball, 1982, s. 345). 
büyük başarısının 1967'de Türkiye'nin adaya müdahalesini önlemek olduğunu açıklamıştır (Aydınlık, 2018). Darbe ve müdahaleyi ABD'nin organizasyonu olarak gören yazarlardan Vanezis ise, normal koşullarda bir askeri cuntanın daha katı bir politika izlemesi gerektiğini savunmaktadır. Halbuki Yunan Cuntasının yönetime geldikten sonraki ilk icraatlarından bir tanesi, $A B D$ ve Türkiye'nin talebine uyup, askerlerini adadan çekmek olmuştur. Yazara göre bu, cuntanın aldığı destek karşılı̆̆ında ABD'yle işbirliği yaptığının ve diyet ödediğinin göstergesidir (Vanezis, 1979, s. 62).

1974 öncesi ABD'nin Kıbrısta taraflar arasında bir silahlı çatışma çıkması ihtimaline karşı hazırladığı son acil durum planı 1971'de yapılmıştır. Burada en kötü ihtimalde bile askeri müdahale bir seçenek olarak ortaya konmamıştır. Aksine 1963 ve 1967'de olduğu gibi yine özel temsilci gönderileceği yazılmıştır ${ }^{12}$. Daha önceki acil durum planlarında da durum aynıdır. Güç kullanmamak konusunda Kongre'nin de benzer bir politika izlediği görülmektedir. Örneğin 19 Temmuz'da Diş İlişkiler Komitesi Başkanı William Fulbright, güç kullanımına karşı olduğunu söylemiş, Senato Çoğunluk Lideri Mike Mansfield ise müdahalenin Vietnam'dan bile kötü sonuçlanacağını savunmuştur (Kissinger, 2000, ss. 542-543). Dolayısıyla ABD'nin Kıbrıs'ta güç kullanmama kararı sürekli politikasının bir devamıdır ve adadaki gelişmelerden memnuniyetinin bir göstergesi değildir.

\section{ABD'nin Kıbrıs Sorununda Etkisiz Kaldı̆̆ına Dair Argümanlar}

Modern Kıbrıs tarihinin en çalkantılı ve belirleyici dönemi olan 1974 yazı, tam da Nixon'un Watergate skandalı nedeniyle tamamen kendi siyasi bekası ile ilgilenmek zorunda kaldığı, ardından istifası sonucu başkanlık değişiminin yaşandığı ve yeni başkan Ford'un görevi henüz devraldığı karışık bir döneme denk gelmiştir. Öncelikle Ecevit'in darbeden 14 gün önce, 1971'deki bir anlaşma ile yasaklanmış olan afyon üretimini tekrar başlatması nedeniyle, Türk-Amerikan ilişkileri zaten bir kriz içerisindedir. Ayrıca skandal nedeniyle, istifa etmek zorunda kalacak olan ilk ve tek ABD başkanı Nixon'un, görevdeki son günlerinde yaşanan Yunan darbesi ve Türk müdahalesi ile ilgilenmek istemediğini belirtmek gerekir. Nitekim

\footnotetext{
12 Planda, son yıllarda Sovyetler Birliği'nin Türkiye'ye doğru kaydığı dolayısıyla çatışmalara karşı tepkisinin sözde kalacağı tahmin edilmiştir (OOTH, 2007a, ss. 912, 919-925).
} 
başkan, 18 Temmuz'da Kissinger'a şunları söylemiştir: 'Her hangi bir taahhütte bulunmamaya çalışacağız. Bu işi sana bırakıyorum." (...) "Kıbrıs'tan uzak durmaya çalı̧mak istiyoruz." Kissinger ise "sadece seni bilgilendirmek istedim, buradan sonrasını ben devralıyorum" (Department of State, 1974) demiştir.

Türkiye'nin ilk müdahalesi sonrasındaki İkinci Cenevre Konferansı'nın başladığı gün Nixon istifa etmiştir. Yunanistan'da cuntanın ve Kıbrıs'ta Nikos Sampson'un düştüğü gün Kissinger, Meclis Adli Kurulu'nda saatlerce ifade vermek zorunda kalmıştır (Constandinos, 2009, s. 331). Türkiye'nin müdahalesinin daha çok tepkiyle karşılanan ikinci safhası ise henüz Ford'un, başkanlığın görev ve sorumlulukları hakkında sürekli olarak briefingler aldığı ve anahtar personelle tanıştırılmakta olduğu dördüncü gününde gerçekleşmiştir. Üstelik, daha yeni göreve gelmiş olan başkan, Kıbrıs sorununun detayları hakkında da yeterli bilgi ve birikime sahip değildir (Kissinger, 1981, ss. 494-495). Dolayısıyla her iki başkan döneminde de ABD Kıbrıs sorununa yoğunlaşamamış ve soruna yönelik esas siyaset belirleyicisi, 1973'ten beri hem dışişleri bakanı hem de başkanın milli güvenlik işleri danışmanlığı pozisyonunu elinde bulunduran Henry Kissinger olmuştur. Arşivlerden anlaşıldığı kadarıyla Kissinger'in ayrıca, Nixon'un gündemini belirleyen, ani krizler hakkında değerlendirme yapan ve istihbarat tarafından yapılan örtülü operasyonları onaylama yetkisi olan (CIA, 2013) komitelerin de başında olduğunu belirtmek gerekir. Bu sebeple söz konusu karışık dönemde yaşananlara yönelik tepkilerin ve eleştirilerin esasen Kissinger'i hedef alması doğaldır.

Öncelikle darbe ve müdahalenin dünya açısından oldukça hareketli bir dönemde gerçekleştiğini belirtmek gerekir. Kissinger için Ortadoğu'da barış çabaları, Güney Amerika'daki komünizm tehlikesi, Petrol Krizi ve SALT II müzakereleri gibi konular yanında Kıbrıs ikinci planda kalmıştır. Kissinger'in, darbe günü Yunanistan'a gönderdiği mesajda, Kıbrıs'ı tek, egemen ve bağımsız bir devlet olarak tanımaya devam ettiklerini ve bu çerçevede ABD'nin, Yunanistan'ın Kıbrıs'taki siyasi ve anayasal düzeni değiştirmesine razı olmayacaklarını söylediği doğrudur (OOTH, 2007b, ss. 283-284). Aynı gün ABD'nin Ankara büyükelçiliğinden gelen mesajda Kissinger'a Türkiye'nin Enosisi engellemek için güç kullanımı dahil her şeyi yapacağı uyarısı yapılmıştır. Bu nedenle büyükelçinin önerisi Enosis ya da Enosise benzeyen her hangi bir eylemin olmaması ve Türklerin zarar görmemesi için $\mathrm{ABD}^{\prime}$ nin tüm gücüyle çalışması olmuştur (OOTH, 
2007b, ss. 287-288). Ancak Kissinger, Savunma Bakanı Schlesinger ile uzlaşı içerisinde bekle gör politikası izlemeye başlamıştır (OOTH, 2007b, ss. 331-332). ABD üst yönetimi, darbe sonrası net bir Yunanistan karşıtı tutum sergilemenin, Türkiye' nin müdahale etmekte kendini daha haklı görmesine ve motive olmasına neden olabileceğinden endişe etmiştir (OOTH, 2007b, s. 319). Nitekim Kissinger de, Yunanistan'ın NATO'dan çıkmaması ve Türkiye' nin müdahale için gerekçe bulamamasını aynı anda sağlamaya çalıştığı için zorlandığını yazmaktadır (Kissinger, 2000, s. 539). Bu hareketsizlik ve arada kalmışlık, ABD'nin etkisiz kalmasındaki nedenler biridir.

Hatıratından ve arşiv bilgilerinden Kissinger' in Sampson'u tanımadığı anlaşılmaktadır. Darbe sabahı yapılan WSAG toplantısında Sampson, Kissinger'a katil ve Enosis'in tutkulu bir savunucusu olarak tanıtılmıştır (OOTH, 2007b, ss. 279-280; Kissinger, 1981, ss. 529-530). Kissinger, darbenin ikinci günündeki Özel Eylemler Grubu (SAG) toplantısında Sampson'u tanımak istemediklerini, 17'sinde ise Sampson'un ABD için en çekici olmayan kişi olduğunu ve onu desteklemenin çıkarlarına olmayacağını açıklamıştır. Kissinger ayrıca Callaghan'dan, Sampson'u desteklemediklerini Türklere iletmesini de istemiştir (Wenzke ve Lindley, 2011, s. 55). Bununla birlikte Kissinger, Sampson konusundaki hoşnutsuzluğuna rağmen bu noktada içeride yapabilecekleri hiç bir şey olmadığını, ilk hedeflerinin meselenin uluslararasılaşmasını ve Sovyetlerin dahiliyetini engellemek olduğunu söylemiştir. BM de konuyu uluslararasılaştırma potansiyeli nedeniyle tercih dışı kalmıştır. Kissinger ayrıca Yunanistanla kavga etmek istemediklerini, müdahilliklerinin düşük düzeyde olacağını söylemiştir (OOTH, 2007b, ss. 279-280). Darbenin ikinci gününde yapılan WSAG toplantısında, Akdeniz'deki ABD Deniz kuvvetlerinin hazırda tutulması kararı alınmışsa da Sisco'nun tavsiyesi de düşük profilli hareket edilmesi, bundan daha fazlasının ters tepebileceği olmuştur. Bu endişeler de ABD'nin etkisiz kalma sebeplerinden bir diğeridir.

Tüm bunlar yaşanırken, Ioannides' in de ABD'nin komünizm konusundaki hassasiyetinden faydalanmaya çalıştı̆̆ını ve yönetimi hareketsiz kalmaya zorladığını belirtmek gerekir. Darbeden 1 ay önce, Tasca'ya ilettiği mesajda, "ya özellikle eğitim sisteminde öğretilen komünist propogandası nedeniyle Kıbrıs sola doğru kayacak ve Akdeniz'in Küba'sı olacaktır ya da \%80'lik 
Rum çoğunluk Yunanistan ile birliğe ulaşacaktır" (OOTH, 2007b, s. 69) demiştir. Darbe'nin hemen sonrasında ABD Büyükelçisi ile yaptığı görüşmede de, Makarios'un pozisyonunu koruyabilmek için adanın \%70'ini oluşturan anti komünistleri feda etmeye kararlı olduğunu söylemiştir (OOTH, 2007b, s. 297). Kibris Radyosu ise darbe sonrasinda hemen Sampson'un keskin bir şekilde komünist karşıtı olan "Milli Kurtuluş Hareketi" bildirisini yayınlamıştır (OOTH, 2007b, s. 300). Ioannides Kissinger'e ulaştırılmak üzere gönderdiği mesajında da, bir gün $\mathrm{ABD}$ hükümetinin 15 Temmuz 1974'te Kıbrıs'ın komünistlerin eline düşmekten kurtulduğunu anlayacağını söylemiştir (Kissinger, 2000, s. 552).

\section{ABD'nin İstihbarat Raporlarını Görmezden Geldiğine Dair Argüman- lar}

27 Ocak 1974'te EOKA-B'nin lideri Grivas'ın ölmesi, Ioanides'in Kıbrıs'a daha doğrudan müdahale etmeye başlamasını da beraberinde getirmiştir. 3 Temmuz 1974'te Makaryos'un kamuoyuna açık şekilde Yunanistan'daki Cunta'yı kendisini devirmek için plan yapmakla suçlamasından sadece 12 gün sonra ise Yunanistan subaylarının liderliğindeki RMMO, EOKAB'nin de desteği ile askeri darbe yaparak Makarios'u görevden uzaklaştırmış ve aslında ilk seçenekleri olmayan eski EOKA'c1 ve komünizm karşıtı Nikos Sampson'u cumhurbaşkanlığına getirmiştir.

Darbe sonrasında çok sayıda araştırmacı gazeteci, ABD yönetiminin Makarios antipatisi ve jeopolitik takıntıları nedeniyle darbeye dair istihbarat raporlarını görmezden geldiğini savunmuştur. Milli Güvenlik Konseyi'nin başı olarak tüm önemli istihbarat raporlarını görebilen Kissinger (Hitschens, 2002, s. 153) bu konuda da oklarm hedefidir. Gazetecilerin ilgili istihbarat raporlarına ulaştığı doğrudur. Ancak Kissinger'a göre dışarıdan bakanların anlayamadığı şey, bu kadar büyük bürokratik bir hükümetin varlığ 1 söz konusuyken, bir araştırmacının her zaman araştırdığı konuyla ilgili ve istediği yönde belge ya da istihbarat raporu bulabileceğidir. Asıl mesele ise bu belgelerin, kimlerin dikkatine ve hangi düzlemde getirilmiş olduğudur (Kissinger, 2000, s. 522). Kissinger, aynı çerçevede 5 Ağustos 1974'te bakanlık görevlileriyle Kıbrıs üzerine yaptığı bir tartışmada da, darbe ihtimalinden bahseden günlük istihbarat raporlarının ol- 
duğunu inkar etmediğini ancak istihbarat görevlilerinin bunları kendisinin ya da başkanın dikkatini çekecek şekilde önlerine getirmediğini savunmuştur. Yöneticilere olması gerektiği şekilde sunulmayan istihbarat ise bir işe yaramamaktadır (Wenske ve Lindley, 2011, s. 50). Nitekim istihbaratın bu konuda zayıf kaldığı ve kimi zaman Ioannides tarafından yanıltıldığı resmi ABD raporlarında da kabul edilmektedir (OOTH, 2007b, ss. 487-488).

Kissinger genel olarak darbeyi sadece kendisinin değil hiç kimsenin tam anlamıla beklemediğini ve durumun bu kadar kritik olduğunu tespit edemediklerini savunmaktadır. Kıbrıs konusunda hep dengeleyici rol oynamış olan İngiltere ve ABD, gelişmeleri 1950ler, 1963, 1964 ve 1967'de çözebildiklerinden daha tehlikeli görmemişlerdir. Üstelik Makarios da 6 Temmuz'da gazetecilere, "darbe olacă̆ını sanmıyorum, olsa da başarılı olamaz" (Mayes, 2000, s. 236) demiş, darbeden sadece 3 gün önce ABD büyükelçisi Rodger Davis'e durumun hassas fakat kritik olmadığını söylemiştir. Kissinger'a göre 15 Temmuz sabahı tüm tarafların hatta Makarios'un bile değerlendirmelerinde yanıldığ1 anlaşılmıştır (Kissinger, 2000, ss. 527529).

Yukarıda anlatılanlara rağmen Kissinger'in, darbenin geleceğinden habersiz olması ya da durumun ciddiyetini anlayamamış olması inandırıc1lıktan uzak görünmektedir. Nitekim 1 Aralık 1972'de Kıbrıs'taki ABD Büyükelçiliğinden gelen raporda, Grivas'ın ne zaman harekete geçeceğini tahmin etmenin güç olduğu ancak muhtemelen Şubat 1974 seçiminden önce harekete geçebileceği yazılmıştır (OOTH, 2007a, s. 1035). ABD arşivlerinden 2 Mart 1972' de Makarios'un başkanlıktan istifasını isteyen Kutsal Sinod üyesi 3 psikoposun da, Yunan hükümeti ile yakın temas içerisinde olduğunun bilindiği anlaşılmaktadır (OOTH, 2007a, s. 1010). Rum Başkan vekili Klerides de, Kıbrıs'taki güvenlik durumunun oldukça kötüye gittiği ve Grivas'ın Makarios'a saldırmak için gizlice büyük miktarda silah ithal ettiği konusunda $\mathrm{ABD}$ büyükelçisini uyarmıştır. Klerides, generalin planını netleştirdiğini ve Makarios'un enosisi dişlayan bir çözüm kabul etmesi ya da başkanlığa tekrar adaylığını koyması durumunda saldırıyı başlatacağını bildirmiştir (OOTH, 2007a, ss. 1032-1033).

1 Temmuz 1974'te Yunan Dış İşleri Bakanlığı'nın Kıbrıs konusunda ılımlı 3 önemli ismi istifa etmiştir. 2 Temmuzda ise Makarios, Cumhurbaşkanı Gizikis'e uzun bir mektup göndermiş ve mektubunda açıkça Cunta 
rejiminini, kendisine ve Kıbrıs hükümetine komplo düzenlemekle suçlamıştır. Başpiskopos ayrıca Atina'dan uzanan ve varlığını ortadan kaldırmayı amaçlayan bir el olduğunu yazmıştır. Cumhurbaşkanının bizzat kendisi Yunanistan tarafından yok edilmek istendiğini basın yoluyla tüm dünyaya ilan ederken Kissinger'in durumun ciddiyetini anlayamamış olması mümkün gözükmemektedir. Nitekim 6 Temmuz'da İngiliz London Times gazetesi bile, Ioannides' in harekete geçmeye karar verdiğini ve komutanlara işi hızlı bir şekilde bitirmeleri durumunda sıkıntı olmayacağının garantisini verdiğini yazmıştır (Mayes, 2000, s. 236).

Kissinger, darbeyi engellemek için çaba harcamadığını da reddetmektedir. Bakan, Yunan cuntasını adada zor kullanarak değişiklik yapmaması konusunda uyarması için Tasca'ya talimat verdiğini ve cuntanın güç kullanma seçeneğinden feragat ettiğini savunmaktadır (Kissinger, 2000, s. 518). Gerçekten de Ioannides'in darbeye girişmemesi konusunda uyarılması için Kissinger, Boyatt ve Sisco'dan Tasca'ya talimatın gittiği, birçok kaynakta yazmaktadır. Örneğin Boyatt, Tasca'ya telgrafında, “Onun bile anlayabileceği bir dille ona (Ioannides'e) söyle, Makarios'un devrilmesi ve Atina yanlısı bir hükümetin getirilmesine özellikle karşıyız. Çünkü eğer bu olursa Türkler işgal edecektir ve bu hiç birimiz için iyi değildir." (Weiner, 2007, s. 332) yazmıştır. Bununla birlikte söz konusu mesajlar Ioannides'e ulaştırılmamış olabilir, nitekim ABD istihbarat raporu Tasca'nın bu müdahaleye karşı çıktığını ve Ioannides yerine Cumhurbaşkanı Ghizikis ile görüştüğünü yazmaktadır (OOTH, 2007b, s. 488).

Tasca, Atina'daki performansı nedeniyle yoğun eleştiriler altında başka göreve alınırken kendisini, "bir büyükelçi olarak siyaset yapıcısı değil siyaset uygulayıcısıydım. Kissinger'in politikası müdahil olmamak üzerineydi." sözleriyle savunmuştur. Mesajı Ioannides'e iletmediği yönündeki eleştirilere karşı ise, bir büyükelçi olarak görevinin bir polise diplomatik girişimlerde bulunmak olmadığını söylemiş (Mayes, 2000, s. 240), “Kissinger ile Sisco'nun günahkeçisi olmayacağım" demiştir (Stern, 1975, ss. 48-51). Halbuki darbeden sadece bir ay önce ABD'ye gönderdiği telgrafinda Tasca, Ioannides ile daha esnek ve etkin iletişim için ayrı ve ilave bir iletişim kanalı açtığını ve buradan kendisine mesaj ulaştırabildiğini 
yazmıştır (OOTH, 2007b, s. 69). Üstelik Tasca, gerçekte Yunanistan'ın, polis dediği Ioannides tarafından yönetildiğini en iyi bilen isimlerdendir. Dolayısıyla Tasca'nın savunmas $1^{13}$ oldukça anlaşılmazdır.

$\mathrm{Bu}$ dönemde ABD'nin yetkili kurumlarının, Yunanistan'ın içişlerine karışıp cuntayı yabancılaştırmamak bahsinde oldukça dikkatli olduğu anlaşılmaktadır. ABD, konuyu uluslararasılaştırmamak için bir iç mesele olarak tutmaya çalışmıştır (Kissinger, 2000, ss. 532-533). Yunanistan'a giden mesajlarda ise Makarios'a karşı bir hareketin Türk-Yunan savaşına neden olabileceği endişesi fazlaca yer almıştır. Bu nedenlerle Ioannides, gelişmeleri Yunanlılar arasında bir iç mesele olarak tutabilmesi durumunda ABD'nin tepki göstermeyeceğini düşünmüş olabilir (Constandinos, 2009, s. 376). Nitekim BM oturumlarında ve medya demeçlerinde cunta temsilcilerinin yaşananları Yunanlılar arası bir iç mesele olarak gösterebilmek için elinden geleni yaptı̆̆ görülmektedir.

ABD'nin Atina Büyükelçisinin uyarıldığı net olsa da, Yunanistan'ın Washington Büyükelçisi'nin ABD Dışişleri Bakanlığı'na çağırılıp uyarıldığına dair bir belge mevcut değildir. Bu şekilde doğrudan bir uyarının olmaması, cunta tarafından üstü örtülü bir yeşil ışık ya da en azından çok sert bir tepki verilmeyeceğinin işareti olarak değerlendirilmiş olabilir. Nitekim İstihbarat ve Araştırma Bürosu Direktörlüğünün 10 Eylül 1974'te Kissinger'a gönderdiği ve bir çok satırının halen gizli tutulduğu memorandumda, (OOTH, 2007b, ss. 487-488) ABD'nin gelmekte olan darbeyi iyi göremediği, konuya yeteri kadar üst düzeyde ve kararlı şekilde yaklaşmadığı ve Ioannides'in Makarios'u güç kullanarak devirmesi durumunda $\mathrm{ABD}$ 'den güçlü bir tepki gelmeyeceğini düşünmüş olabileceği değerlendirilmiştir.

\section{Sonuç}

Soğuk Savaş dönemi boyunca süper güçler, hassas güç dengesini koruyabilmek ve nükleer bir savaşla sonuçlanabilecek maceralara sürüklenmemek adına, kendi etki alanlarındaki etnik çatışmaları mümkün olduğunca sınırlamaya çalışmışlardır. Bununla birlikte söz konusu hassas güç dengesi, kendi milli hedeflerini önceleyen Kıbrıslı Rum ve Türkler

${ }^{13}$ Bugün Tasca'nın savunması halen gizlilik derecelidir. (Kutler, 1990, Dipnot 37) 
için, büyük güçlerle pazarlık unsuru olmak dışında fazla bir anlam ifade etmemiştir. Kıbrıs sorunu nedeniyle Atlantik İttifak'ın stratejik öneme sahip güney doğu kanadının zayıflamasından endişe eden ABD ise aslında eleştirilerin aksine Kıbrıs konusunda kısa vadeli ya da belirsiz değil, oldukça istikrarlı bir politika izlemiştir. İncelenen tüm belgelerin ışı̆̆ında anlaşılmaktadır ki ABD'nin KC'nin kurulmasından 1974'e kadarki asli politikaları; Türkiye ile Yunanistan'ın savaşmasına müsaade etmemek, Kıbrıs'ın Doğu Kampına kaymasına izin vermemek, Sovyetler Birliği'nin soruna dahil olmasına engel olmak, Kıbrıs konusunda askeri güç kullanmamak ve hem Türkiye hem de Yunanistan'1 kaybetmemeye çalışmak olmuştur. ABD, dönem boyunca tüm kararlarını, bu politikaların uygulanabilmesine yönelik almış ve gerektiğinde demokrasi ya da insan haklarına dair sorunları görmezden gelebilmiştir.

ABD'nin Kıbrıs'a dair politikası istikrarlı olmakla birlikte, başarılı olarak değerlendirilemez. ABD'nin bir yandan dünyadaki diğer önemli meselelerle uğraşırken diğer yandan Kıbrısla ilgili çok sayıda çatışan hedefi aynı anda sağlamaya çalışması, bunun asli nedenidir. Örneğin Yunanistan ile ilgili iki çatışan çıkar uzlaştırılmaya çalışılmıştır: Bir yanda Doğu Akdeniz'deki stratejik çıkarlarını korumak, üslerden faydalanabilmek ve Yunanistan'ın NATO üyesi kalmasını sağlamak; diğer yanda ise başta Kongre'den gelen olmak üzere, askeri diktatörlüğe karşı çıkılması ve demokrasinin desteklenmesi yönündeki baskıları karşılayabilmek (OOTH, 2007b, ss. 655-656). Ancak Kissinger hem demokrasinin doğduğu yer olarak bilinen bir ülkede faşist bir yönetim uygulayan cuntaya destek vermenin utancını yaşamış hem de Yunanistan'ın NATO'nun askeri kanadından çekilmesine ve 1973 'te üslerle ilgili imzalanan antlaşmayı feshetmesine engel olamamıştır. ABD'li büyükelçi Nicholas Burns 1998'de, Başkan Clinton ise 1999'daki Yunanistan ziyaretinde, “ABD, Soğuk Savaş çıkarlarını, demokrasiyi destekleme çıkarını önüne koydu, halbuki Soğuk Savaşı zaten bunun için veriyorduk. Bunu kabul etmeliyiz" (Associated Press, 1999) diyerek, cuntaya verilen destekten ötürü pratikte özür dilemiştir.

Kissinger'ın aynı anda gerçekleştirmeye çalıştı̆̆ı diğer iki çatışan çıkar ise Türkiye'nin müdahalesini engellemek ama aynı zamanda onu kaybetmemektir. Kissinger bunda da başarısız olmuş, hem müdahaleyi engelle- 
yememiş hem de sonrasındaki silah ambargosu nedeniyle Türkiye'yle ilişkilerini bozmuştur. Bu süreçte stratejik İncirlik Üssü bile ABD'nin kullanımına kapatılmıştır.

Nihayetinde hem Türk hem de Yunan tarafı, 1974'te yaşananlar nedeniyle ABD'ye tepki duymaktadır. Ancak Kıbrıs'ta varılan noktanın, Türkiye'nin yıllardır savunduğu taksime daha yakın olduğu ve Türk Silahlı Kuvvetleri'nin halen adada olduğu düşünüldüğünde, ABD'nin krizde Yunanistan yerine Türkiye'yi tercih etmiş olduğu savunulabilir. Nitekim Kissinger hatıratında, "her ne kadar hükümetine dair çekincelerim varsa da Yunanistan'ın izole edecek politikaları reddettim, çünkü NATO stratejimizin çok önemli bir parçasıydr. Ancak Türkiye daha da çok önemliydi. Türkiye'nin tüm Soğuk Savaş boyunca ittifak için yaptıkları ve jeostratejik önemi, yaptırımlar konusunda olağanüstü isteksiz olmamin nedeniydi." demiştir. (Kissinger, 2000, ss. 579-580) ABD'nin en yakın müttefiki İngiltere'nin hazırladığı raporda da Batı'nın stratejik çıarları için Türkiye'nin, Yunanistan'dan daha önemli olduğu ve "eğer bir ilişki riske atılmak zorunda kalınırsa, Türklerle değil Yunanlılarla ilişkilerin kötüleşmesini seçmek gerektiği." (Mallinson, 2009, s. 117) açıkça yazılmıştır.

Kıbrıs'taki hayati gelişmelerin ABD tarafından şekillendirildiğine yönelik argümanlar gelecekte de muhtemelen savunulmaya devam edilecektir. Ancak, tüm olayların arka planında Amerikan çıkarlarının olduğu yönündeki argümanlar, adadaki gelişmelerin rasyonelden ziyade tepkisel bir refleks ile karşılanmasına neden olmaktadır. Müzakerelerde ortaya konan önerilere ya da çözüm planlarına da aynı nedenle şüphe ile yaklaşılmaktadır. Üstelik bunları makul bulup uzlaşmak isteyenlerin de, ülkelerinin değil Amerikan çıarlarına hizmet etmekle suçlanmaları söz konusu olmaktadır. Bu da muhalefetin baskısı altındaki hükümetleri ve temsilcilerini ister istemez daha katı ve uzlaşmaz bir tavır içerisine sokmaktadır. Dolayısıyla, özellikle modern Kıbrıs tarihinin dönüm noktalarından olan 1974 Darbesi'nde ABD'nin ne kadar rolü olduğunu açıklığa kavuşturabilmek, Kıbrıs Sorunun çözümüne katkı anlamında da önemlidir.

ABD'nin; İran'da Muhammed Musaddık'a karşı darbeden (BBC, 2013), Küba' da Domuzlar Körfezi Çıkarmasına (BBC, 2011), Yunanistan'daki Albaylar Darbesinden, Şili'de Salvador Allende'nin devrilmesine, (ABC, 2000) Fidel Castro'ya yönelik suikast girişimlerinden (NBC, 2007) Güney Amerika'daki seçim müdahalelerine (Levin, 2016, ss. 1-19) kadar Soğuk 
Savaş'ın birçok önemli gelişmesinde örtülü ya da açık rolü olduğu artık arşivlerin de desteğiyle bilinmektedir. Dolayısıyla 1974'te Kıbrıs'ta da benzer bir yöntemi izlemiş olması elbette mantık dışı değildir. Ancak bu çalışma yapılırken incelenen belgelerden; ABD'nin Sovyet ve komünizm yanlısı olduğu gerekçesiyle Makarios'u devirmek istediğine, bu nedenle cunta tarafından yapılan darbeyi desteklediğine ve böylece; üs ve tesisleri güvence altına almayı, Türkiye'yi askeri müdahale yönünde teşvik etmeyi ve adayı NATO etki alanına sokmayı planladığına dair kanıta ulaşılamamıştır. Bununla birlikte, gelecekte ortaya çıkması muhtemel yeni belge ve bilgilerin, mutlaka dikkatli bir şekilde takip edilmesi gerekmektedir. 


\title{
EXTENDED ABSTRACT
}

\section{USA's Role in 1974 Cyprus Military Coup}

\author{
Altuğ Günal
}

Ege University

Cyprus had been an important island in the Mediterranean for the West, the East and the Non-Aligned. While non-aligned generally tried to protect Makarios as he was one of the important figures of the movement; NATO did its best to prevent Cyprus from shifting to the East Block. The USSR did not want Cyprus to fall into NATO's sphere of influence, and saw the continuation of the disputes on the island as a useful tool for keeping NATO's southeastern flank weak. It preferred a low tensioned crisis between Cypriots which also meant crisis between NATO allies Turkey and Greece. In this context, in February 1964, Kruschev rejected NATO's proposal for the situating of peacekeeping forces on the island and declared that the USSR would not be indifferent to the island.

On August 16, 1960, after long lasting conflicts and political crises, the Republic of Cyprus emerged as an independent state. On the same day, the United States recognized this new state and launched its diplomatic relations, raising its consulate in Nicosia to the embassy. The priorities of the USA on Cyprus between 1960-1974 were, ensuring the island's stability so that it won't; cause a clash between Turkey and Greece, weaken the NATO cooperation in the Eastern Mediterranean, seek alliance with Soviets and create an opportunity for USSR to be involved in the problem. However, Makarios, the president of 1960 Republic of Cyprus, had incorporated his country into the Non-Aligned Movement and developed good relations with the East Camp, and particularly the USSR. In addition to these, he had problems with NATO Allies Greece and Turkey and took support from the communist party of Cyprus. Thanks to this, he began to be called Castro of the Mediterranean. Naturally, the US administrations under Cold War conditions had been discontent with these developments. 
In July 1974, the NATO ally Greece under junta rule, organized a coup in Cyprus and overthrew Makarios. While many European countries condemned the coup; USA gave a soft response, refrained from cutting its military aid to Greece, was reluctant to reinstate Makarios and refused to use force to stop the coup or subsequent Turkish intervention. These developments have created arguments, which defended that the United States supported the coup and Turkey's subsequent military intervention, in order to put Cyprus under NATO influence.

This study, within definite neutrality, attempts to reveal how much the US had a role in 1974 Cyprus Coup, which is considered to be among the most critical periods of the modern Cypriot history. In this context, the author examines the US archives that are published in print and online, and secondary sources as well.

In the framework of the sources examined, this study argues that there is not enough proof to assert that the 1974 Coup in Cyprus had taken place with the approval or support of the United States. Throughout the period, Cyprus struggled with its own internal problems and tried to remain independent of the poles. While Turkey and Greece were trying to pursue their traditional theses, USA had continued to implement steadily its primary policies mentioned above. Although the US was uncomfortable with some of Makarios' policies, it didn't see him as anti-Western or dangerous enough. Indeed, the use of force to eliminate a leader that the majority of Greeks supported and found legitimate does not make sense in terms of the stability of the region and the uncertainty of its consequences as well. It should also be noted that in the 1970s, when many important developments took place in the world, Cyprus was not among the top priorities for the US despite its geostrategic importance.

US is now known for its implicit or explicit role in the many important developments of the Cold War such as the coup against Mohammad Mossadegh in Iran, the Bay of Pigs Invasion in Cuba, the Colonel's Coup in Greece, the overthrow of Salvador Allende in Chile, assassination attempts to Fidel Castro and the South American electoral interventions. Consequently, the possibility that US followed a similar method in Cyprus in 1974 is certainly not irrational. However, in the context of the documents examined during this study, there is no explicit proof that, in order 
to put the island under NATO influence USA soughed to overthrow Makarios on the grounds that he was pro-Soviet and communist and he posed threat for bases and facilities on the island. However, new documents and information likely to arise in the future should be followed carefully.

\section{Kaynakça / References}

Asmussen, J. (2008). Cyprus at war: Diplomacy and conflict during the 1974 crisis. London: I.B. Tauris.

Ball, G. (1982). The past has another pattern: Memoirs. New York: Norton\&Company.

BMGK Resmi Kayıtları 1779 Sayılı Karar. (1974). Erişim Tarihi 22 Kasım 2018. http://repository.un.org/bitstream/handle/11176/71407/S_PV.1779-EN.pdf?sequence $=17$ \&isAllowed $=y$.

BM'den Kıbrıs'a Amerikan Şahini. (5 Temmuz 2018). Aydınlık. Erişim Tarihi 20 Temmuz 2018. https://www.aydinlik.com.tr/bm-den-kibris-a-amerikan-sahini-turkiye-temmuz-2018.

CIA. (2 Ekim 1964). Probability of attacks against Us troops sent to Cyprus. Erişim Tarihi 3 Eylül 2018. http://www.faqs.org/cia/docs/81/0000567713/probability-of-attacks-against-us-troops-sent-to-cyprus.html\#ixzz5uwnn6s7e.

CIA Admits Involvement in Chile. (20 Eylül 2000). ABC. Erişim Tarihi 9 Nisan 2018. https://abcnews.go.com/International/story?id$=82588 \&$ page $=1$.

CIA Acknowledges Castro Plot Went to Top. (26 Haziran 2007). NBC. Erişim Tarihi 9 Nisan 2018. http://www.nbcnews.com/id/19444072/ns/politics/t/cia-acknowledges-castro-plot-wenttop/\#.WBq8i4XfjvY.

CIA. (19 Mart 2013). Chronology of the 40 Committee. Erişim Tarihi 20 Kasim 2018. https://www.cia.gov/library/readingroom/docs/LOCHAK-301-1-9-6.pdf.

CIA'in 1953'teki İran darbesinde rol oynadığ 2013). BBC. Erişim Tarihi 9 Nisan 2018. https://www.bbc.com/turkce/haberler/2013/08/130820_iran_cia. 
Clinton Leaves Greece After Apology for Past Policies Statement Meant As Reconciliation After Friday's Riots. (21 Kasım 1999). Associated Press. Erişim Tarihi 11Aralık 2018. https://www.deseretnews.com/article/729125/Clinton-leaves-Greece-after-apologyfor-past-policies.html.

Cypriots Believe CIA Tried to Kill Makarios, Not Pay Him. (24 Şubat 1977). The Washington Post. Erişim Tarihi 3 Eylül 2018. https://www.washingtonpost.com/archive/politics/1977/02/24/cypriots-believe-cia-tried-to-kill-makarios-not-pay-him/3749e8962dcf-4037-8a24-4e7b4e525819/?noredirect=on\&utm_term=.01e23a5fe7c2

Contandinos, A. (2009). America, Britain and Cyprus Crisis of 1974: Calculated conspiracy or foreign policy failure. Authorhouse.

Constandinos, A. (2011). US-British policy on Cyprus, 1964-1974. The Cyprus Review, 23(1), 17-48.

Department of State. (24 Şubat 1972). VI: I: Initial Letter of Inquiry to State Department, Committee on Foreign Affairs, House of II. Response of State Department to Initial Lettter. Washington, Erişim Tarihi 10 Aralık 2018. https://babel.hathitrust.org/cgi/pt?id=uc1.a0000082529 ; view=1up;seq=8.

Department of State. (18 Temmuz 1974). President Nixon/ Secretary Kissinger, Telecon. Erişim Tarihi 20 Kasım 2018. http://foia.state.gov/documents/Kissinger/0000C9F8.pdf.

Domuzlar Körfezi çıkarması: Mükemmel fiyasko. (15 Nisan 2011). BBC. Erişim Tarihi 9 Nisan 2018. https://www.bbc.com/turkce/haberler/2011/04/110414_bay_of_pigs.

Greece Withdrawing Units From NATO to Aid Cyprus. (18 Ağustos 1964a). New York Times. Erişim Tarihi 15 Ağustos 2018. https://www.nytimes.com/1964/08/18/archives/greecewithdrawing-units-from-nato-to-aid-cyprus.html.

Güney, A. (2004). The USA's Role in Mediating the Cyprus Conflict: A Story of Success or Failure?. Security Dialogue, 35(1), 27-42.

Hakk1, M.M. (2007). The Cyprus ıssue: A documentary history: 1878-2007. New York: I. B. Tauris. 
Hare, R. A. \& Mak, D. (22 Temmuz 1987). The association for diplomatic studies and training foreign affairs oral history project. Erişim Tarihi 10 Şubat 2018. https://cdn.loc.gov/service/mss/mfdip/2004/2004har03/2004har03.pdf.

Hitchens, C. (2002). The trial of Henry Kissinger. London: Verso.

John F. Kennedy Başkanlık Kütüphanesi ve Müzesi. https://www.jfklibrary.org/asset-viewer/archives/JFKWHP/1962/Month\%2006/Day\%2005/JFKWHP-1962-06-05-B.

Kıbrıs Cumhuriyeti Dış İşleri Bakanlığı. Erişim Tarihi 8 Ocak 2018. http://www.mfa.gov.cy/mfa/mfa2016.nsf/All/DAFAC26FB139D6 CEC2257F9C0042B2F0?OpenDocument.

Kissinger, H. (2000). Years of renewal (1. bs.). New York: Touchestone.

Kutler, S. I. (1990). The wars of watergate: The last crisis of Richard Nixon. New York: A Knopf Book.

Levin, D. H. (2016). Partisan electoral interventions by the great powers: Introducing the PEIG dataset. Conflict Management and Peace Science, 1-19. https://www.halifaxexaminer.ca/wp-content/uploads/2018/07/Levin-study.pdf

Lindsay, J.K. (2011). The Cyprus problem:What everyone needs to know. Oxford: Oxford University Press.

Makarios: Cypriot Nationalism Incarnate. (4 Ağustos 1977). Washington Post. Erişim Tarihi 11 Mart 2017. https://www.washingtonpost.com/archive/politics/1977/08/04/makarios-cypriot-nationalism-incarnate/24ef5cf9-3d6a-40b8-ae5928206e5ec588/?utm_term $=.6 \mathrm{~b} 3 \mathrm{c} 65 \mathrm{ce} 8 \mathrm{~d} 26$.

Mallinson, W. (2009). Cyprus, Britain, the USA, Turkey and Greece in 1977: Critical Submission or Submissive Criticism?. Journal of Contemporary History, 44(4), 737-752.

Mallinson, W. (2011). Britain and Cyprus: Key themes and documents since world war II. NewYork: I.B. Tauris.

Mayes, S. (2000). Makarios: A biography. London: Mac Millan Press.

Mirbargheri, F. (1998). Cyprus and international peacemaking. London: Hurst.

O'Malley, B. ve Craig, I. (1999). The Cyprus conspiracy: America, Espionage and the Turkish invasion. New York: I.B. Tauris \& Co Ltd. 
Office of the Historian. A Guide to the United States' History of Recognition, Diplomatic, and Consular Relations, by Country, since 1776: Cyprus. Erişim Tarihi 7 Temmuz 2018. https://history.state.gov/countries/cyprus.

Office of the Historian. (2007a). Document 261: Memorandum From the President's Assistant for National Security Affairs (Kissinger) to President Nixon (Foreign Relations of the United States, 1969-1976, Volume XXIX, Eastern Europe; Eastern Mediterranean, 1969-1972). Washington: Government Printing Office.

Office of the Historian. (2007a). Document 272: Response to National Security Study Memorandum (Foreign Relations of the United States, 19691976, Volume XXIX, Eastern Europe; Eastern Mediterranean, 1969-1972). Washington: Government Printing Office.

Office of the Historian. (2007a). Document 330: National Intelligence Estimate Source (Foreign Relations of the United States, 1969-1976, Volume XXIX, Eastern Europe; Eastern Mediterranean, 1969-1972). Washington: Government Printing Office.

Office of the Historian. (2007a). Document 367: Information Memorandum From the Assistant Secretary of State (Foreign Relations of the United States, 1969-1976, Volume XXIX, Eastern Europe; Eastern Mediterranean, 1969-1972). Washington: Government Printing Office.

Office of the Historian. (2007a). Document 369: Telegram From the Department of State to the Embassy in Turkey (Foreign Relations of the United States, 1969-1976, Volume XXIX, Eastern Europe; Eastern Mediterranean, 1969-1972). Washington: Government Printing Office. Office of the Historian. (2007a). Document 376: Minutes of the Senior Review Group Meeting (Foreign Relations of the United States, 1969-1976, Volume XXIX, Eastern Europe; Eastern Mediterranean, 19691972). Washington: Government Printing Office.

Office of the Historian. (2007a). Document 378: Action Memorandum From the Assistant Secretary of State for Near Eastern and South Asian Affairs (Sisco) to Secretary of State Rogers (Foreign Relations of the United States, 1969-1976, Volume XXIX, Eastern Europe; Eastern Mediterranean, 1969-1972). Washington: Government Printing Office. 
Office of the Historian. (2007a). Document 398: Minutes of the Washington Special Actions Group Meeting (Foreign Relations of the United States, 1969-1976, Volume XXIX, Eastern Europe; Eastern Mediterranean, 1969-1972). Washington: Government Printing Office.

Office of the Historian. (2007a). Document 407: Information Memorandum From the Assistant Secretary of State for Near Eastern and South Asian Affairs (Sisco) to Secretary of State Rogers (Foreign Relations of the United States, 1969-1976, Volume XXIX, Eastern Europe; Eastern Mediterranean, 1969-1972). Washington: Government Printing Office.

Office of the Historian. (2007a). Document 408: Telegram From the Embassy in Greece to the Department of State (Foreign Relations of the United States, 1969-1976, Volume XXIX, Eastern Europe; Eastern Mediterranean, 1969-1972). Washington: Government Printing Office.

Office of the Historian. (2007a). Document 411: Telegram From the Embassy in Greece to the Department of State (Foreign Relations of the United States, 1969-1976, Volume XXIX, Eastern Europe; Eastern Mediterranean, 1969-1972). Washington: Government Printing Office.

Office of the Historian. (2007a). Document 416: Record of Department of State Roundtable Discussion (Foreign Relations of the United States, 1969-1976, Volume XXIX, Eastern Europe; Eastern Mediterranean, 1969-1972). Washington: Government Printing Office.

Office of the Historian. (2007a). Document 417: Telegram From the Embassy in Cyprus to the Department of State (Foreign Relations of the United States, 1969-1976, Volume XXIX, Eastern Europe; Eastern Mediterranean, 1969-1972). Washington: Government Printing Office.

Office of the Historian. (2007a). Document 418: Telegram From the Embassy in Cyprus to the Department of State (Foreign Relations of the United States, 1969-1976, Volume XXIX, Eastern Europe; Eastern Mediterranean, 1969-1972). Washington: Government Printing Office.

Office of the Historian. (2007b). Document 14: Telegram From the Embassy in Greece to the Department of State (Foreign Relations of the United States, 1969-1976, Volume XXX, Greece; Cyprus; Turkey, 19731976). Washington: Government Printing Office. 
Office of the Historian. (2007b). Document 15: Interagency Intelligence Memorandum (Foreign Relations of the United States, 1969-1976, Volume XXX, Greece; Cyprus; Turkey, 1973-1976). Washington: Government Printing Office.

Office of the Historian. (2007b). Document 72: Intelligence Note Prepared in the Bureau of Intelligence and Research (Foreign Relations of the United States, 1969-1976, Volume XXX, Greece; Cyprus; Turkey, 1973-1976). Washington: Government Printing Office.

Office of the Historian. (2007b). Document 80: Minutes of Meeting of the Washington Special Actions Group (Foreign Relations of the United States, 1969-1976, Volume XXX, Greece; Cyprus; Turkey, 1973-1976). Washington: Government Printing Office.

Office of the Historian. (2007b). Document 82: Telegram From the Department of State to the Embassy in Greece (Foreign Relations of the United States, 1969-1976, Volume XXX, Greece; Cyprus; Turkey, 19731976). Washington: Government Printing Office.

Office of the Historian. (2007b). Document 85: Telegram From the Embassy in Turkey to the Department of State (Foreign Relations of the United States, 1969-1976, Volume XXX, Greece; Cyprus; Turkey, 19731976). Washington: Government Printing Office.

Office of the Historian. (2007b). Document 86: Minutes of Meeting of the Washington Special Actions Group (Foreign Relations of the United States, 1969-1976, Volume XXX, Greece; Cyprus; Turkey, 19731976). Washington: Government Printing Office.

Office of the Historian. (2007b). Document 89: "Telegram From the Embassy in Greece to the Department of State (Foreign Relations of the United States, 1969-1976, Volume XXX, Greece; Cyprus; Turkey, 19731976). Washington: Government Printing Office.

Office of the Historian. (2007b). Document 94: Minutes of Meeting of the Washington Special Actions Group (Foreign Relations of the United States, 1969-1976, Volume XXX, Greece; Cyprus; Turkey, 19731976). Washington: Government Printing Office.

Office of the Historian. (2007b). Document 95: Memorandum of Conversation Washington (Foreign Relations of the United States, 1969-1976, Volume XXX, Greece; Cyprus; Turkey, 1973-1976). Washington: Government Printing Office. 
Office of the Historian. (2007b). Document 97: Telegram From the Department of State to Certain Posts (Foreign Relations of the United States, 1969-1976, Volume XXX, Greece; Cyprus; Turkey, 1973-1976). Washington: Government Printing Office.

Office of the Historian. (2007b). Document 100: Transcript of Telephone Conversation Between Secretary of State Kissinger and Secretary of Defense Schlesinger (Foreign Relations of the United States, 1969-1976, Volume XXX, Greece; Cyprus; Turkey, 1973-1976). Washington: Government Printing Office.

Office of the Historian. (2007b). Document 103: Transcript of Telephone Conversation Between President, Nixon and Secretary of State Kissinger (Foreign Relations of the United States, 1969-1976, Volume XXX, Greece; Cyprus; Turkey, 1973-1976). Washington: Government Printing Office.

Office of the Historian. (2007b). Document 119: Memorandum of Conversation (Foreign Relations of the United States, 1969-1976, Volume XXX, Greece; Cyprus; Turkey, 1973-1976). Washington: Government Printing Office.

Office of the Historian. (2007b). Document 120: Telegram From the Embassy in Cyprus to the Department of State (Foreign Relations of the United States, 1969-1976, Volume XXX, Greece; Cyprus; Turkey, 19731976). Washington: Government Printing Office.

Office of the Historian. (2007b). Document 148: Memorandum From the Director of the Bureau of Intelligence and Research (Hyland) to Secretary of State Kissinger (Foreign Relations of the United States, 19691976, Volume XXX, Greece; Cyprus; Turkey, 1973-1976). Washington: Government Printing Office.

Office of the Historian. (2007b). Document 257: Draft Memorandum for the President (Foreign Relations of the United States, 1969-1976, Volume XXX, Greece; Cyprus; Turkey, 1973-1976). Washington: Government Printing Office.

Office of the Historian. (2018). Document 174: Letter from Prime Minister Karamanlis to President Eisenhower (Foreign Relations of the United States, 1958-1960, Vol.X, Part 1: Eastern Europe Region; Soviet Union; Cyprus). Washington: Government Printing Office. 
Office of the Historian. (2018). Document 257: "Draft Memorandum for the President (Foreign Relations of the United States, 1958-1960, Vol.X, Part 1: Eastern Europe Region; Soviet Union; Cyprus). Washington: Government Printing Office.

Office of the Historian. (2018). Document 310: Letter From the British Ambassador (Caccia) to Acting Secretary of State Herter (Foreign Relations of the United States, 1958-1960, Vol.X, Part 1: Eastern Europe Region; Soviet Union; Cyprus). Washington: Government Printing Office.

Office of the Historian. (2018). Document 347: Statement of US Policy Toward Cyprus (Foreign Relations of the United States, 1958-1960, Vol.X, Part 1: Eastern Europe Region; Soviet Union; Cyprus). Washington: Government Printing Office.

Packard, M. (2008). Getting it wrong: Fragments from a Cyprus Diary 1964. Authorhouse.

President John F. Kennedy meeting Archbishop Makarios, the President of Cyprus. (2 Temmuz 2013). Erişim Tarihi 21 Nisan 2018. https://www.youtube.com/watch?v=HsQ_hA91PiY.

Presidential Elections 1959-2013. (2018). Erişim Tarihi 20 Mart 2018. http://www.elections2018.gov.cy/downloads/presidential-elections-1959-2013-en.pdf.

Roberts, S. (26 Aralık 1976). One Year Later, the Murder of the C.I.A.'s Chief Officer in Athens Remains a Mystery Without Solid Clues. New York Times. Erişim Tarihi 2 Ocak 2019. https://www.nytimes.com/1976/12/26/archives/one-year-later-the-murder-of-thecias-chief-officer-in-athens.html.

Stern, L. (1975). Bitter lessons: How we failed in Cyprus. Foreign Policy, 19, 34-78.

Tamçelik, S. (1998). Kıbrıs Komünist Parti'nin (AKEL) İlhak Kararı ve SSCB'nin Kıbrıs Politikası. II. Uluslararası Kıbrıs Araştırmaları Kongresi, Gazimağusa, Doğu Akdeniz Üniversitesi: 1-16.

Tamçelik, S. (2011). Kıbrıs'taki İngiliz üslerinin stratejik önemi. Uluslararasi Insan Bilimleri Dergisi, 8(1), 1510-1539.

Text of Parallel Letters by Khrushchev on Cyprus. (8 Şubat 1964b). New York Times. Erişim Tarihi 4 Ekim 2018. http://www.nytimes.com/1964/02/08/text-of-parallel-letters-by-khrushchev-oncyprus.html?_r=0. 
The National Archives. Erişim Tarihi 6 Aralık 2018. https://aad.archives.gov/aad/createpdf?rid=64807\&dt=2474\&dl=1345.

The Secret Committee Called '40'. (19 Ocak 1975). New York Times. Erişim Tarihi 20 Kasım 2018. https://www.nytimes.com/1975/01/19/archives/the-secret-committee-called-40-at-least-in-theory-it-controlsthe.html.

Uzer, U. (2010). Identity and Turkish foreign policy. London: I. B. Tauris.

Vanezis, P. N., (1979). Makarios: Life and leadership. London: Abelard-Schuman.

Weiner, T. (2007). Legacy of Ashes: History of CIA. London: Doubleday.

Yakinthou. (2009). Political settlements in divided societies: Consociationalism and Cyprus. New York: Palgrave.

Wenzke, C. ve Lindley, D. (2011). Dismantling the Cyprus Conspiracy: The United States Role in the Cypriot Crises of 1963, 1967, 1974. University of Notre Dame Working Paper in Progress.

Wikileaks. (5 Eylül 1974). Tito Takes Pessimistic View Of Cyprus, Middle East Situation; Blames Cia and Nato For Makarios Overthrow. Erişim Tarihi 25 Kasım 2015. https://wikileaks.org/plusd/cables/1974BELGRA04533_b.html.

\section{Kaynakça Bilgisi / Citation Information}

Günal, A. (2019). ABD'nin 1974 Kıbrıs askeri darbesindeki rolü. OPUSUluslararası Toplum Araştırmaları Dergisi , 10(17), 2168-2207. DOI: 10.26466/ opus.521229 